\title{
The impact of temporary employment and employment protection on labour productivity: evidence from an industry-level panel of EU countries
}

\author{
Domenico Lisi
}

Accepted: 11 January 2013 / Published online: 5 February 2013

(C) Institut für Arbeitsmarkt- und Berufsforschung 2013

\begin{abstract}
In recent years the availability of new industrylevel data allowed to evaluate the impact of labour market policies more consistently than previous standard crosscountry studies. In this paper an industry-level panel is exploited to evaluate the impact of Employment Protection Legislation (EPL) for temporary employment (TE), along with permanent employment (PE), in EU countries. Indeed, the advantage of using industry-level data is manifold. The method exploits both cross-country variation in EPL for PE and TE and variation in the relevance of EPL in different industries deriving from a particular diff-in-diff assumption. Differently from the previous literature we apply this idea of the different binding of EPL only for PE, whereas we implement a different strategy for TE which should imply a more accurate identification of the effect of the use of TE on labour productivity. The theoretical literature has not established a clear prediction on the sign of the effects, existing different convincing reasons for both directions. Thus, the results of the analysis have potentially important policy implications. Our main finding is that the use of temporary contracts has a negative, even if small in magnitude, effect on labour productivity. Furthermore, the analysis confirms that EPL for regular contracts reduce labour productivity growth more in those industries requiring a greater employment reallocation.
\end{abstract}

The author would like to thank Stephen Machin, Roberto Cellini, Sergio Destefanis, two anonymous referees and participants in various conferences and seminars for helpful comments and suggestions. However, the analysis and errors remain responsibility of the author alone.

D. Lisi $(\bowtie)$

University of Catania, Catania, Italy

e-mail: domenico.lisi@unict.it
Keywords Labour productivity - Temporary employment . EPL $\cdot$ Difference-in-differences $\cdot$ IV

JEL Classification J08 $\cdot$ J24 $\cdot$ O47

\section{Einfluss von befristeter Beschäftigung und \\ Kündigungsschutz auf die Arbeitsproduktivität: \\ Evidenz aus einem branchenspezifischen Panel von EU-Ländern}

Zusammenfassung In den letzten Jahren ermöglichten neue, auf Branchenebene verfügbare Daten eine genauere Evaluation des Einflusses der Arbeitsmarktpolitik als frühere ländervergleichende Analysen. In diesem Aufsatz wird ein branchenspezifisches Panel genutzt, um den Einfluss des Kündigungsschutzes auf befristete und unbefristete Arbeitsverhältnisse in den EU-Ländern zu ermitteln. Die Vorteile dieser Datengrundlage sind vielfältig. Die Methode nutzt sowohl die internationale Variation beim Kündigungsschutz für befristete und unbefristete Arbeitsverhältnisse als auch die Variation von Branche zu Branche. Im Unterschied zur bisherigen Literatur wenden wir die Idee der unterschiedlichen Bindungskraft des Kündigungsschutzes nur für unbefristete Beschäftigungsverhältnisse an, während wir für befristete Beschäftigungsverhältnisse eine andere Strategie anwenden, die eine genauere Identifikation des Effekts unbefristeter Beschäftigungsverhältnisse auf die Arbeitsproduktivität ermöglicht. Die theoretische Literatur erlaubt noch keine klare Vorhersage zum Vorzeichen dieses Effekts, da unterschiedliche überzeugende Gründe für Effekte in beide Richtungen bestehen. Daher haben die Ergebnisse der Analyse möglicherweise wichtige politische Implikationen. Unsere Haupterkenntnis ist, dass befristete Verträge einen negativen, wenn auch sehr geringen Effekt auf die Arbeitsproduktivität haben. Desweiteren bestätigt die Analyse, 
dass Kündigungsschutz bei regulären Arbeitsverträgen das Wachstum der Arbeitsproduktivität in den Branchen drosselt, die auf eine stärkere Beschäftigungsallokation angewiesen sind.

\section{Introduction}

Despite the international differences in the relative importance of temporary employment (TE), it is evident that in the last decades temporary jobs have been becoming an important feature of the labour market landscape in the majority of OECD countries. In particular, the share of TE in most EU countries has grown dramatically, both in the form of fixedterm contracts (FTC) and temporary work agencies (TWA), raising the question of the possible effects of this structural change in the labour market.

In the different experiences of EU countries a considerable number of country-specific factors have been playing an important role in determining this change. Nonetheless, as emphasized by a growing literature, some common determinants appear to have been crucial in shaping this feature. In particular, the high employment protection (EPL) for permanent employment (PE) along with a less stringent regulation for TE would seem to be the main explanation of the rapid growth of TE in EU countries. Similarly, the low protection for PE in the United States, the United Kingdom and other countries would explain the low use of TE made by employers.

The new scenario has raised concern over the potential increase of the dualism in the labour market between high protected workers finding a stable job and those low protected remaining in the trap of precariousness, with little prospect of upward mobility. Moreover, temporary contracts frequently offer less access to the welfare system and other fringe benefits, as unemployment insurance, sick leave, paid vacations (see Appendix 3, Table 12). Indeed, this dualism would represent an undesirable difference between the welfare conditions of these two worker types in the society.

From an efficiency point of view, the increasing share of TE raises the question of what would be the impact on labour productivity. This issue would have potentially very important policy implications, especially since in the last twenty years labour productivity growth accounted for more than half of GDP growth in OECD countries (OECD 2003).

The theoretical literature available so far has not established a clear prediction on the sign of the effect of TE, existing different convincing reasons for both directions. On one hand, TE is disproportionally filled by younger and less educated workers, and temporary workers often have less access to training programmes (OECD 2002 and 2007a). Moreover, given the temporary, and frequently short, duration of contracts it would be rationale for a firm to fix a lower reservation productivity under which to layoff temporary workers than permanent ones, in order to avoid the direct and indirect firing costs (Lisi 2012). On the other hand, TE allows firms a much more flexible and efficient organization of resources and, in turn, eliminates the disincentive to invest in risky, but potentially valuable, projects (Engellandt and Riphahn 2004). Moreover, it might be rationale for temporary workers to exert a greater effort in order to get the renewal of the contract and/or the passage to a stable job (Dolado and Stucchi 2008). Therefore, the issue of the direction of the effect remains an empirical question.

Similarly, while the literature has already offered a convincing answer to the issue of the role of EPL for PE on employment level, the theoretical literature available so far has not fully clarified what is the impact on labour productivity. Indeed, this question has been already the object of interest of few empirical studies, some of which succeed in identifying the negative impact of EPL for permanent contracts (e.g. Bassanini et al. 2009). However, the strategy to identify the impact of TE does not seem to be as satisfactory as that for PE. Nonetheless, to these studies has to be acknowledged the merit to have introduced an identification strategy more satisfactory than the previous standard crosscountry analysis.

Following this new empirical literature, the aim of this paper is to shed light on this issue by assessing the impact of both EPL for PE and TE (both FTC and TWA) on labour productivity growth. To the extent that the level of TE and EPL affects firms decision on investment and, in turn, the level of capital affects labour productivity growth, we estimate a reduced form model to capture the overall effect, assuming a Cobb-Douglas production function with constant returns to scale. The empirical strategy follows a diff-in-diff approach introduced in the finance literature by Rajan and Zingales (1998) and later extended in other areas in economics. In the field, Micco and Pagés (2006) and Bassanini and Venn (2007) introduced this approach to evaluate the impact of different labour market policies. The method exploits both cross-country variation in EPL for PE and TE and variation in the relevance of EPL in different industries deriving from a particular diff-in-diff assumption.

However, differently from the previous literature we apply this idea of the different binding of EPL across industries only for permanent employment, whereas we implement a different strategy for TE. In fact, as will be argued ahead in the paper, the use of the variation in the EPL index for TE does not seem a proper approach to identify the impact of TE. Differently, it would seem more appropriate to use directly the variation in the share of TE. In this way we should be able to isolate the impact of TE on labour productivity growth, without passing through the relation between the change in the EPL for TE and actual use of temporary contracts in the labour market. Moreover, to the extent that the share of TE might be endogenous and, in particular, driven 
by the same unobservable factors driving labour productivity, we perform an IV-estimate to check the robustness of our findings. To this extent, our more accurate identification of the effect of the use of TE on labour productivity should represent a valid contribution to the literature.

The main result is that TE has a negative impact on labour productivity growth, even if small in magnitude. In particular, an increase of 10 percentage points of the share of TE would lead to a decrease of about $2-3 \%$ in labour productivity. Furthermore, the analysis confirms the findings of the previous literature that EPL for regular contracts reduce labour productivity growth more in those industries requiring for their own characteristics a greater employment reallocation.

The paper proceeds as follows: Sect. 2 introduces the main stylized facts about labour market regulation and, in particular, TE in EU countries. Then, Sect. 3 reviews briefly the previous literature and discusses some theoretical issues. Section 4 illustrates the identification strategy and introduces the main features of the dataset. Later on, Sect. 5 presents the results of the analysis and examines the robustness of our findings. In conclusion, Sect. 6 discusses the policy implications and some final remarks.

\section{Labour market and reforms: the stylized facts}

In the 1990s the persistency of a high level of unemployment in Europe compared to other OECD countries represented a reason of concern for many governments. Consequently, most of EU countries felt the need to reform the labour market legislation, identified as one of the main causes of high unemployment.

Despite the different forms of intervention, the majority of labour market reforms followed a fairly common scheme: new legislations did not included workers hired pre-reforms, instead affecting deeply the rules for those post-reforms; the protection legislation for PE were left untouched; the use of TE was gradually liberalized.

The emergence of these asymmetric institutional changes can be well characterized by Fig. 1 (Boeri and Garibaldi 2007a). It illustrates the evolution of the OECD index of the strictness of EPL for both regular ${ }^{1}$ (top) and temporary (bottom) employment ${ }^{2}$ between the late 1980s and 2003. In the

\footnotetext{
${ }^{1}$ This index is calculated by scoring different basic items concerning employment protection of regular workers against individual dismissal and, then, converting these scores into a cardinal index from 0 to 6 , with a higher index representing a stricter regulation (see OECD, Employment Outlook 1999, Chap. 2, Appendix 2.B). Therefore, a higher index implies more protection for regular workers against individual dismissal.

${ }^{2}$ The procedure to compute the index for temporary workers is fairly the same described in footnote 1. However, the EPL index for TE does
}
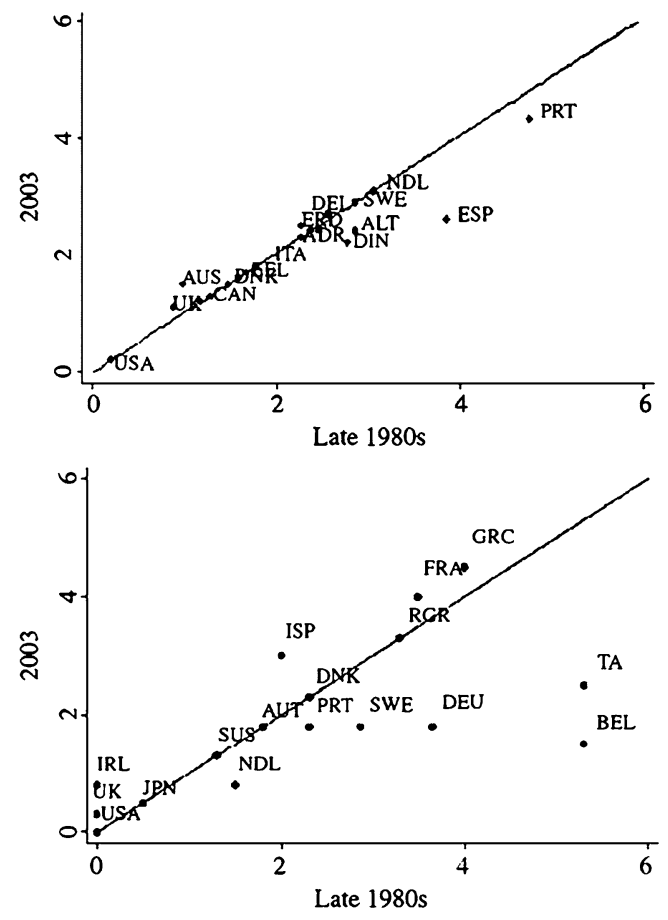

Fig. 1 OECD index of the strictness of EPL for permanent (top) and temporary (bottom) contracts

Figure at the top very few countries are located below the $45^{\circ}$ line, suggesting that protection rules for PE were left unchanged. In this regard, Spain and Portugal constitute an exception, where respectively in 1997 and 2001 protection legislations for permanent contracts were significantly relaxed. Differently, in the figure at the bottom very few countries lie close to the bisector, indicative of the extensive reformatory process concerning the use of TE.

In order to provide some insights into the macro-impact of this extensive reformatory process in the labour market, in the Fig. 2 we report the graphs of unemployment rate and growth rate, along with the percentage of temporary workers, in the transition time (1995-2005) of a wide sample of EU countries. To select those countries experiencing what we have identified as the standard labour market reform, we could make use of the Fig. 1, selecting those EU countries staying far from the $45^{\circ}$ line in the figure at the bottom concerning TE. Following this criteria, an appropriate sample could be: Belgium, Germany, Netherlands, Italy, Portugal, Spain, Sweden. Indeed, as it can be seen from Fig. 1 (bottom), in Spain between the late 1980s to 2003 there was a restriction on the use of TE, rather than a liberalization. Nonetheless, the liberalization process in Spain started in

not measure the degree of protection of temporary workers against individual dismissal, rather it measures the restrictions on the use of temporary forms of employment (see OECD 2004). Therefore, a higher index does not imply more protection against individual dismissal, rather it implies stricter conditions for using temporary employment. 

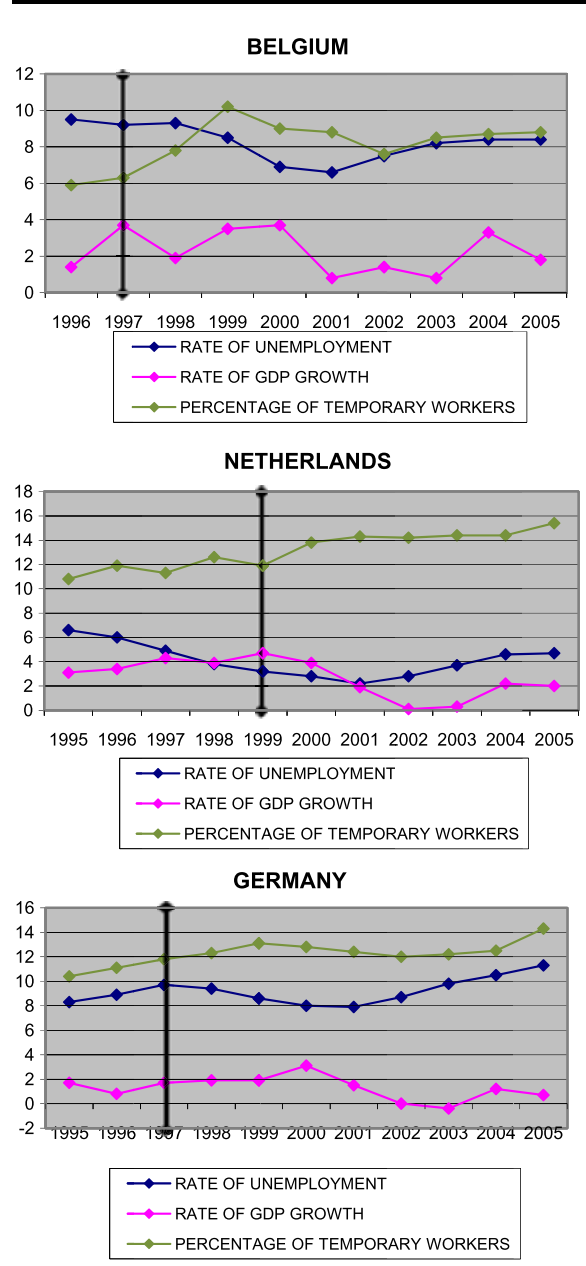
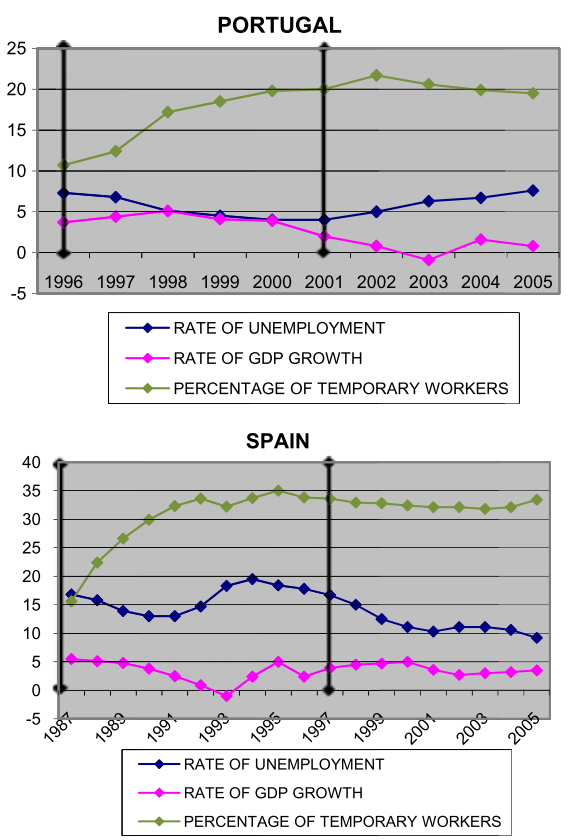

FRANCE

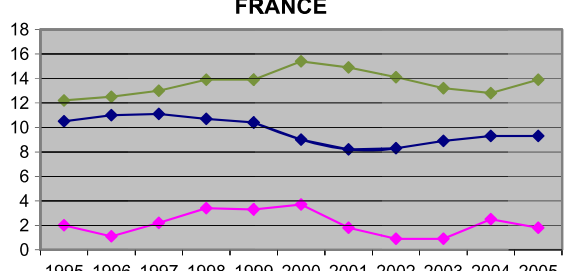

19951996199719981999200020012002200320042005

$$
\begin{aligned}
& \longrightarrow \text { RATE OF UNEMPLOYMENT } \\
& \longrightarrow \text { RATE OF GDP GROWTH } \\
& \rightarrow \text { PERCENTAGE OF TEMPORARY WORKERS }
\end{aligned}
$$

Reform dates:

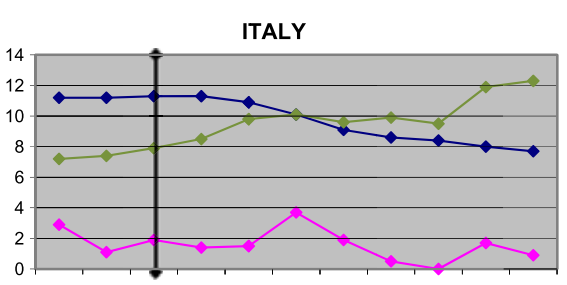

19951996199719981999200020012002200320042005 $\rightarrow-$ RATE OF UNEMPLOYMENT $\rightarrow$ RATE OF GDP GROWTH $\rightarrow$ PERCENTAGE OF TEMPORARY WORKERS

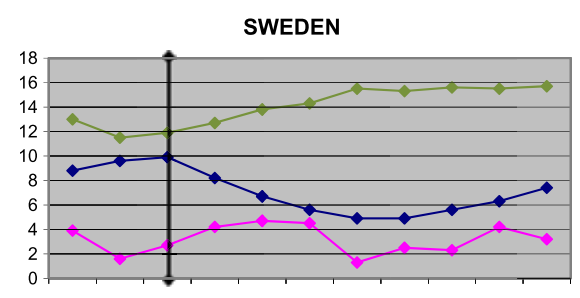

19951996199719981999200020012002200320042005
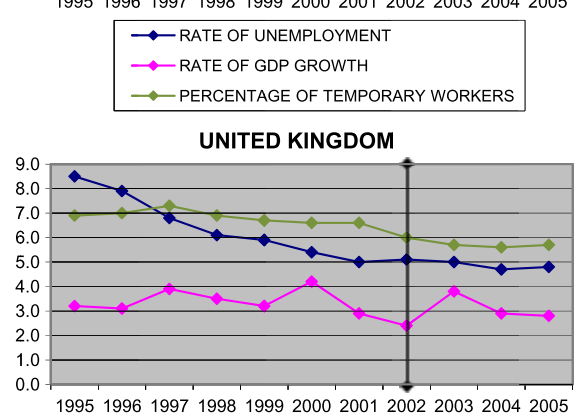

19951996199719981999200020012002200320042005

$$
\begin{aligned}
& \rightarrow \text { RATE OF UNEMPLOYMENT } \\
& \rightarrow \text { RATE OF GDP GROWTH } \\
& \rightarrow-\text { PERCENTAGE OF TEMPORARY WORKERS }
\end{aligned}
$$

Belgium 1997; Portugal 1996-2001; Italy 1997;

Netherlands 1999; Spain 1985-1997; Sweden 1997;

Germany 1996; United Kingdom 2002;

Fig. 2 Unemployment rate, growth rate and percentage of TE in EU countries

the early 1980s, before the time period covered. ${ }^{3}$ Finally, we include also France and the UK for their importance in the European context.

At the bottom of the Fig. 2 we report the reform dates for all countries, indicated also by the vertical bold lines in each graph. For Spain and Portugal we report two dates, the first one concerning the liberalization of TE and the second one the reduction in the protection for PE. On the other hand, no date is reported for France, since in the selected period there was not any relevant change in the regulation for TE. ${ }^{4}$ To get these dates we made use of the $f r d b$ (Fondazione Rodolfo De

\footnotetext{
${ }^{3}$ Moreover, as can be seen from the Fig. 1 (top), in Spain and Portugal there was not only a change in the regulation for TE, but also a reduction in the protection for $\mathrm{PE}$.

${ }^{4}$ Indeed, in France the relevant reform for TE was implemented in 1990, where have been limited the circumstances in which the use of
}

Benedetti) inventory of social policy reform. ${ }^{5}$ This dataset records detailed information about social reforms, included EPL, in EU15 countries. Indeed, in fairly all countries in the sample there was more than one reform, as a result of the political convenience to make the reformatory process more gradual. Following the previous literature, we identify the "reform" in a country as the most important and crucial intervention in this gradual process.

With the caveat of a graphical analysis in mind, from Fig. 2 we can identify some important macro-facts characterizing those countries experiencing the typical reformatory process described above. In particular, we can observe that in these countries, after the liberalization of TE, there was

TWA and FTC is permissible and their maximum duration has been reduced.

${ }^{5}$ See www.frdb.org for more details. 
a decrease in unemployment and an increase in growth. After the first years, there was a slackening in growth, despite the employment was keeping to increase, condition often labelled in the literature as growthless job creation (e.g. Boeri and Garibaldi 2007a). Finally, there was a realignment of the unemployment rate towards the pre-reform level.

On the other hand, another common denominator was the strong contribution of temporary contracts to the increase in employment. Despite the data deny the common perception that OECD countries failed to generate new permanent jobs, it is certainly true that a big part of employment growth was driven by TE, especially in Europe. In particular, as highlighted by different OECD Employment Outlook in the last years (e.g. OECD 2002 and 2007a), the growth of temporary jobs accounted for at least two-thirds of total employment growth in Austria, Finland, France, Germany, Italy and it played a considerable part in Belgium, the Netherlands, Portugal, Spain, Sweden, the United Kingdom.

Even if there was no reform concerning TE, a similar picture would seem to emerge in France between 1997-2003, just in correspondence with the expansion of the share of TE. Differently, the 2002 reform in the UK does not seem to have led to the same macro-facts. But in fact, reducing the maximum total duration of FTC, the UK reform has restricted (instead of relaxed) the use of TE, as confirmed by the gradual reduction of the share of TE in the figure.

To some extent, these stylized facts subsequent to the liberalization of TE seem to highlight that the use of TE does not affect only the level of employment. In particular, the evidence of the extensive part of TE on job creation, along with the so called growthless job creation condition, raises fairly naturally the worry about what effect the new regime could have had on labour productivity growth. In addition, this impact would be particularly relevant, given the predominant role of labour productivity growth in underpinning the income growth in the last twenty years (OECD 2003). The rest of this paper intends to shed light on this question, to clarify if the common lines followed by European governments in reforming labour market legislation correspond really to the principles of best practices.

\section{Previous literature on EPL and theoretical issues}

The previous literature on EPL (both for PE and TE) is an immense object and a complete survey goes beyond the aim of this paper. Nonetheless, in this section we review briefly a selected (the most relevant for our purpose) part of it and, then, discuss some theoretical issues surrounding the impact on labour productivity.

The first focus of the literature has been the effect of EPL for PE on labour demand. The traditional analysis of labour demand under uncertainty was pioneered by Nickell (1978) and extended by Bentolila and Bertola (1990). In these labour demand models with sticky wages and adjustment costs, EPL are not neutral but have a negative impact on both firing and hiring decisions. Labour market general equilibrium models come to the similar conclusion that protection legislations affect negatively job flows (Garibaldi 1998; Mortensen and Pissarides 1999). A considerable number of empirical studies tend to confirm these theoretical predictions (e.g. Blanchard and Portugal 2001; Autor et al. 2006; Messina and Vallanti 2007).

Nonetheless, the effect on average labour demand would seem ambiguous, since there is no reason to believe à priori that the disincentive to hire should be greater or smaller than that to fire. Indeed, there are theoretical reasons to propend for both a positive (e.g. Fella 2004) and a negative effect (e.g. Garibaldi and Violante 2005; Samaniego 2006). Thus, it is not surprising that there has been a proliferation of empirical studies trying to give an answer to this question. Still, as emphasized by Baker et al. (2004), both signs and magnitudes of the estimated impact vary considerably to draw a definitive conclusion on the direction of the effect (e.g. Bertola 1990; Nickell et al. 2005; Destefanis and Mastromatteo 2010).

All studies considered so far focus on the structural effect of EPL for PE on labour market performance. Recently, some studies concentrate more on the transitional dynamics of partial EPL reform liberalizing the use of TE. Boeri and Garibaldi (2007a) claim that there is a relation between the growthless job creation condition and the asymmetric reformatory process carried out by EU countries. In particular, they analyze a dynamic and stochastic labour demand model before and after the introduction of temporary contracts and firing restrictions for workers hired pre-reform. They find a honeymoon effect, that is a positive but only temporary effect of TE on employment and a fall in labour productivity, due to decreasing returns to scale.

In recent years the interest of the literature has shifted more towards the impact of layoff protection on productivity growth. On one hand, a higher worker protection could distort the efficient allocation of resources, reducing productivity growth (Hopenhayn and Rogerson 1993; Saint-Paul 1997). For instance, in Saint-Paul (2002) it is shown that a high protection legislation, reducing leeway for firms, could dampen their propensity to innovate. Moreover, higher EPL could be an impediment for the adoption of new technologies (Bartelsman and Hinloopen 2005). Similarly, in Samaniego (2006) it is emphasized that a high worker protection could prevent the optimal reallocation from declining to growing industries. Finally, Riphahn (2004) and Ichino and Riphahn (2005), focusing on the behavioural component of labour productivity, find that EPL reduces the incentive to exert effort for workers, due to the lower threat of layoff in response to low performance. On the 
other hand, higher EPL could promote a greater cooperation through stable relationships, inducing workers to exert a higher effort (Fella 2004). Similarly, longer job tenure could make both firms and workers more willing to invest in firm-specific human capital, enhancing productivity growth (Belot et al. 2002). Nonetheless, the cross-country evidence on the effect of EPL on productivity is still inconclusive (e.g. Nickell and Layard 1999; Koeniger 2005; DeFreitas and Marshall 1998).

Indeed, cross-country studies could suffer from serious drawbacks, making the interpretation of results at least problematic. In particular, the majority of these studies could be affected by an endogeneity problem for at least two reasons. First, it might be the case that labour market policies are affected by labour market conditions, making the estimated coefficients bias for the simultaneity problem. Second, since several factors driving cross-country differences are not observable by the econometrician, the EPL coefficient might pick up the effect of the omitted variables. For instance, the level of social and cultural capital in a given country represents something very difficult to measure and, consequently, it is often not considered by econometricians, probably just because do not exist reliable measures of it. Nonetheless, it is likely to represent a crucial factor driving cross-country differences on productivity. Therefore, if EPL are correlated with the levels of social and cultural capital, and probably they are, then the EPL coefficient might pick up the effect of them as well. Another relevant problem could be the use of EPL index as independent variable in the regression analysis. Since EPL for PE have been often left untouched by reforms, it would be questionable if there is sufficient variation to reach the identification of the effect. Consequently, many studies were forced to insert the overall EPL index in the regression analysis, without distinguishing between PE and TE, even if it would certainly be more correct to keep these two covariates distinct.

Differently from the standard cross-country analysis, some recent empirical studies exhibit a more convincing identification strategy. In Micco and Pagés (2006) the authors use a difference-in-differences approach on an industry-level dataset of OECD and non-OECD countries, to identify the effect of EPL on the level of labour productivity. Their main identification assumption is that EPL are much more binding in those industries characterized by a larger necessity to reallocate resources. In particular, the main idea of the binding/non-binding strategy is that although firing restrictions imposed on firms by more stringent EPL are formally equal across sectors in a country, indeed they should be more binding in those industries requiring a higher job reallocation for their own physiological characteristics as technological changes, stability of tastes, incidence of aggregate shocks. Therefore, this different binding across industries should induce an ulterior exogenous source of vari- ation on the impact of the policy which can be exploited in the empirical analysis.

The main problem with this identification strategy is that, since the actual turnover rates are themselves affected by EPL, they cannot be used as the natural need to reallocate resources in industries. Therefore, to discriminate sectors between binding industries and non-binding industries, the authors use turnover rates in the US, where firms decision on job flows are taken essentially in a frictionless environment. In particular, they find that EPL have a negative impact on the level of labour productivity. However, as the theoretical literature suggests, it would seem more appropriate to allow the empirical specification to control for the effect of EPL on long-run labour productivity growth, rather than only on the level of labour productivity. Additionally, their finding would seem to depend too much on the presence of Nigeria in the sample, invalidating the generalization of results. Moreover, as cross-country studies, they use the overall EPL index rather than to distinguish between PE and TE.

The same identification strategy has been extended by Bassanini and Venn (2007), OECD (2007a) and Bassanini et al. (2009), apparently overcoming the previous drawbacks. In particular, they control for the effect of EPL on productivity growth and distinguish between EPL for regular and temporary contracts. They find that EPL for regular contracts have a negative effect on TFP growth, whereas do not find any effect of EPL for temporary contracts.

Using a similar methodology, this paper intends to enhance the understanding of the effect of labour market regulation on labour productivity growth, focusing on temporary contracts. Indeed, though acknowledging all merits to previous studies, it is our opinion that they fail to reach the identification of the effect of TE on productivity growth.

In particular, while the EPL index for regular contracts is certainly a correct independent variable, we believe that the EPL index for temporary contracts does not seem to be the appropriate independent variable to identify the effect of temporary contracts. The EPL index for regular contracts expresses the degree of layoff protection for permanent workers (see footnote 1). Therefore, it certainly influences firms and workers behaviour on investment and effort, affecting directly labour productivity. Differently, the EPL index for temporary contracts does not express the degree of layoff protection, rather the permissiveness to use temporary contracts (see footnote 2). Therefore, the legislation on TE influences labour productivity only to the extent firms actually use temporary contracts. Evidently, the EPL index affects the use of TE by firms, but it is certainly difficult to establish what is the relation between the timing of a reform introducing the use of temporary contracts and their actual use and expansion in the labour market. Thus, provided that we check for the potential endogeneity of TE, it would seem more appropriate to use directly the variation in the share of 
TE, rather than the EPL index for temporary contracts. In this way we should be able to isolate the impact of TE on labour productivity growth, without passing through the relation between the change in the EPL for TE and actual use of temporary contracts in the labour market. Moreover, using the share of TE as covariate instead of the EPL index for TE, we do not need to rely on some assumption concerning how much the EPL index is binding in different industries.

Indeed, from a theoretical point of view it is not clear what might be the effect of the use of temporary contracts on labour productivity. On one hand, temporary workers often have less access to training programmes and TE is disproportionally filled by younger, less educated and less experienced workers (OECD 2002 and 2007a; Bassanini et al. 2007). Furthermore, temporary workers occasionally suffer less pleasant working conditions and usually they feel less satisfied respect to regular workers with job security and pay (see Tables 13 and 14). Additionally, given the temporary and frequently short duration of contracts it might be rationale for a firm to fix a lower reservation productivity under which to layoff temporary workers than permanent ones, in order to avoid the direct and indirect firing costs (Lisi 2012). ${ }^{6}$

On the other hand, TE allows firms a much more flexible and efficient organization of resources and, in turn, eliminates the disincentive to invest in risky, but potentially valuable, projects (Engellandt and Riphahn 2004). Moreover, as long as temporary workers are able to affect the probability of renewal by a higher effort, it might be rationale for them to exert a greater effort in order to get the renewal of the contract and/or the passage to a stable job (Dolado and Stucchi 2008).

Thus, the effects of TE and EPL for PE on labour productivity remains an empirical question.

\section{Empirical strategy and data}

In this section we illustrate the empirical strategy used in the study, describing all steps from initial assumptions to estimating equations. Then, the main features of the data are introduced.

\subsection{Empirical specification}

The empirical strategy follows the method introduced in the finance literature by Rajan and Zingales (1998) to evaluate the impact of some market regulations, then extended

\footnotetext{
${ }^{6}$ In particular, in that paper it is shown that, as long as temporary worker perceives a sufficiently low conditional probability of getting the renewal of the contract and/or the passage to a stable job, there might be a scope for exerting an effort level just in line with the firm reservation productivity, which indeed for temporary workers should not be especially high. From this perspective, the use of temporary contracts might induce a reduction in labour productivity.
}

in labour policy evaluation by Micco and Pagés (2006) and Bassanini and Venn (2007). The main assumption of this approach is that while the degree of market regulation is equal for all industries in a given country, the impact of it could be different among industries, according to some physiological characteristics of each sector. In the case of labour market regulation, it is reasonable to expect that EPL are more binding in those industries characterized by a higher need to reallocate resources. For instance, if firms in a given sector need to lay off workers in response to changes in technologies or product demand, a stricter employment protection could slow the pace of reallocation. By contrast, in industries where changes in technologies and demand are less frequent or where firms can reallocate labour through internal adjustments, changes in EPL could be expected to have little impact on reallocation and, in turn, on productivity. Indeed, in this study we maintain these assumptions only for the EPL index for regular contracts, whereas we do not assume a different binding for temporary contracts, given that we use directly the share of TE as explanatory variable.

As far as EPL studies are concerned, the main problem is to recover an appropriate measure of the natural need of job reallocation in each industry. In fact, since the actual turnover rates are themselves affected by EPL, they should not be used as a reliable index for the natural need of job reallocation. The method proposed by Rajan and Zingales (1998) to deal with this problem is to use data from a frictionless country as a proxy for the physiological characteristics of each industry. Following this idea, a standard approach to classify industries in EPL studies is to use turnover rates in the US, usually considered the quintessential frictionless country (Micco and Pagés 2006; Bassanini and Venn 2007 and Bassanini et al. 2009).

Dividing industries in binding industries (B) and nonbinding industries $(\mathrm{NB})$, the difference between total factor productivity growth in B and NB can be modelled as a function of some index of the degree of regulation, in our case the EPL index for PE:

$$
\overline{\Delta \log T F P}_{i t}^{B}-\overline{\Delta \log T F P}_{i t}^{N B}=f\left(E P L_{i t}\right)
$$

where the first element indicates the average of total factor productivity growth over B in country $i$ at time $t$, the second element the same for NB and $f$ is some function. Moreover, notice that the EPL index does not vary across industries.

The diff-in-diff specification (1) is the main assumption exploited in the previous literature to identify the impact of the EPL index for both PE and TE. However, in this study while we maintain this assumption for the EPL index for PE, for the reasons stated above we believe that the EPL index for TE does not seem to be the appropriate independent variable to identify the effect of temporary contracts. Differently, in our empirical analysis we use the share of TE as the main explanatory variable of interest. To some extent, 
provided that we control for the potential endogeneity of TE, this should allow us to capture the effect of the use of temporary contracts without passing through the relation between the change in the EPL for TE and actual use of temporary contracts in the labour market.

If we assume that $f$ in (1) is linear, then we could estimate the impact of TE along with the EPL for PE using both a specification in levels or in growth rates:

$$
\begin{aligned}
\log T F P_{i j t}= & \alpha\left(B I_{j} * \sum_{k=1}^{t} E P L_{i k}\right)+\beta \sum_{k=1}^{t} E P L_{i k} \\
& +\gamma \sum_{k=1}^{t} T E_{i j k}+\sigma \sum_{k=1}^{t} X_{i j k}+\mu_{i}+\delta_{j} \\
& +\varphi_{t}+\varepsilon_{i j t} \\
\Delta \log T F P_{i j t}= & \alpha\left(B I_{j} * E P L_{i t}\right)+\beta E P L_{i t}+\gamma T E_{i j t} \\
& +\sigma X_{i j t}+\theta_{t}+\omega_{i j t}
\end{aligned}
$$

The two specifications presume the same data generating process, in fact specification (3) is the first-difference version of specification (2) with $\theta_{t}=\varphi_{t}-\varphi_{t-1}$ and $\omega_{i j t}=$ $\varepsilon_{i j t}-\varepsilon_{i j t-1}$. In both specifications $\alpha$ is the marginal effect of EPL for PE on TFP growth in binding industries, $\gamma$ is the marginal impact of the share of temporary contracts, $B I_{j}$ is a binary indicator equal to 1 if $j$ is binding, $X_{i j t}$ are other independent variables affecting TFP growth such as trade union density and time trend $\left(T_{t}=t, \forall t=1,2, \ldots, 14\right)$, whereas $\mu_{i}, \delta_{j}$ and $\varphi_{t}$ represent respectively country, industry and time-specific fixed effects allowed to be correlated with other covariates.

Under the exogeneity assumption $E\left(\varepsilon_{i j t} \mid E P L_{i t}, T E_{i j t}\right.$, $\left.X_{i j t}, \mu_{i}, \delta_{j}, \varphi_{t}\right)=0$ both fixed-effects (2) and first-difference (3) estimating equations produce unbiased and consistent estimates of the parameters of interest, therefore the choice between them concerns exclusively the efficiency of the estimation. In particular, it is well-known that the fixed-effects estimator is the most efficient estimator under the assumption of idiosyncratic errors $\varepsilon_{i j t}$ serially uncorrelated; on the other hand, the first-difference estimator is more efficient when $\varepsilon_{i j t}$ follows a random walk, which means that there is very substantial serial correlation. In this regard, with $T$ large and $N$ not so large and especially if one is dealing with unit root processes, first-difference estimator has the advantage of ruling out the unit root, implying that one can still appeal to the central limit theorem even with $T$ larger than $N$. Differently, when $N$ is consistently larger than $T$, the serial correlation of the error term should not represent a big problem. Moreover, if the strict exogeneity assumption is somehow violated, event we investigate below in the paper, fixedeffects estimator is likely to exhibit substantially less bias than first-difference. ${ }^{7}$ Hence, in our case with $N=130$ and $T=14$, there might be a scope for choosing fixed-effects for the greater efficiency, provided that one includes in the estimation the time trend and the variance estimator robust to heteroskedasticity and serial correlation. In addition, regardless of the theoretical assumption on the idiosyncratic error term, in cases where the explanatory variables do not exhibit a sufficient amount of variation in both dimensions (time and cross-section) the first-difference transformation might further reduce their variation and, thus, the first-difference estimator might in practice produce estimates with very little precision. For all these reasons, though we report also the first-difference estimates, in this paper we consider the fixed-effect estimates as more reliable and, therefore, as the main source of our interpretation.

Indeed, in the binding/non-binding specifications one is compelled to fix a rule to divide all industries between binding and non-binding and, then, to consider the impact in all binding industries equal to each other and the impact in all non-binding industries equal to zero. Instead of dividing industries between binding and non-binding, it might be more correct to weight the impact of EPL for PE with some plausible natural rate of job reallocation for each industry. This different approach leads us to the following diff-in-diff specification:

$\overline{\Delta \log T F P}_{i j t}-\overline{\Delta \log T F P}_{i k t}=f\left(F J R_{j}-F J R_{k}\right) * E P L_{i t}$

from which we get

$$
\begin{aligned}
\log T F P_{i j t}= & \alpha\left(F J R_{j} * \sum_{k=1}^{t} E P L_{i k}\right)+\beta \sum_{k=1}^{t} E P L_{i k} \\
& +\gamma \sum_{k=1}^{t} T E_{i j k}+\sigma \sum_{k=1}^{t} X_{i j k}+\mu_{i}+\delta_{j} \\
& +\varphi_{t}+\varepsilon_{i j t}
\end{aligned}
$$

where $F J R_{j}$ is some reliable measure of the natural rate of job reallocation in each industry. To some extent, in the specification (5) the interpretation of $\alpha$ is less direct than in (2), but still meaningful. In particular, it tells us how TFP growth changes in an industry with a relatively high need of job reallocation (HJR) with respect to an industry with a relative low one (LJR) when the EPL index increases. For instance, if the estimated coefficient is negative, then this indicates that TFP growth in HJR decreases with respect to that in LJR, meaning that EPL for PE have a negative impact on productivity growth.

The usual approach in EPL literature is to use turnover rates in the US, that is $F J R_{j}=U S J R_{j}$. Nonetheless, the use of US turnover rates has not been exempt from criticisms in

\footnotetext{
${ }^{7}$ See Wooldridge (2010) for more details
} 
the literature. In particular, it has been noted that the appropriateness of this approach relies on the homogeneity of sectors classification across countries in the sample. In a recent paper Cingano et al. (2010) discuss this problem, showing as within sector heterogeneity would limit the validity of the use of the US data as a proxy for the natural rate of job reallocation in other countries. Additionally, it has been claimed that this approach would produce a short rather than a longrun measure of job reallocation, due to the incidence of aggregate shocks to the actual data (Fisman and Love 2007 and Ciccone and Papaioannou 2006, 2007).

In the same paper Ciccone and Papaioannou (2006) developed a method to obtain a measure of physiological rate of job reallocation in each industry, depurated from the frictions introduced by labour market regulation and the effect of aggregate shocks. In particular, they regress the actual job reallocation rate at industry level on industry dummies $\pi_{j}$, industry dummies interacted with the EPL index for PE $\tau_{j} * E P L_{i t}$ and country-time dummies $\vartheta_{i t}$ :

$J R_{i j t}=\pi_{j}+\tau_{j} * E P L_{i t}+\vartheta_{i t}+v_{i j t}$

The presence of country-time dummies $\vartheta_{i t}$ should control for any time-varying differences across countries, whereas the interaction term $\tau_{j} * E P L_{i t}$ should absorb the effect of market regulation on job reallocation rate, allowing us to obtain an appropriate estimate $\hat{\pi}_{j}$ of natural rate of job reallocation in each industry. In the paper by Cingano et al. (2010) they compare the results obtained with the two methods to assess the appropriateness of the standard approach to use the US data, concluding in favour of the second method. Hence, in the following empirical analysis we will use the frictionless measure obtained from (6), that is we will use $F J R_{j}=\hat{\pi}_{j}$, bounding the use of binding/non-binding approach only for sensitive analysis. Following Davis and Haltiwanger (1992) and Cingano et al. (2010), we define the job reallocation rate as:

$J R_{i j t}=\frac{\left|E_{i j t}-E_{i j t-1}\right|}{\left(E_{i j t}+E_{i j t-1}\right) / 2}$

where $E_{i j t}$ is the level of employment in industry $j$, in country $i$, at time $t$. Evidently, this measure treats symmetrically job creation and job destruction, in accordance with the theoretical literature (e.g. Bentolila and Bertola 1990; Mortensen and Pissarides 1999).

Following the previous literature, we assume a CobbDouglas production function with constant returns to scale at the industry level:

$Y_{i j t}=A_{i j t} K_{i j t}^{\rho} L_{i j t}^{1-\rho}$

where $Y_{i j t}$ is total output, $A_{i j t}$ is total factor productivity, $K_{i j t}$ is capital and $L_{i j t}$ is labour. To obtain the estimating equation we divide for $L_{i j t}$, take the logs and substitute (5) in (8):

$$
\begin{aligned}
\log y_{i j t}= & \rho \log k_{i j t}+\alpha\left(\hat{\pi}_{j} * \sum_{k=1}^{t} E P L_{i k}\right)+\beta \sum_{k=1}^{t} E P L_{i k} \\
& +\gamma \sum_{k=1}^{t} T E_{i j k}+\sigma \sum_{k=1}^{t} X_{i j k} \\
& +\mu_{i}+\delta_{j}+\varphi_{t}+\varepsilon_{i j t}
\end{aligned}
$$

where $y_{i j t}$ is labour productivity, $k_{i j t}$ is the capital-labour ratio and the remainder is as in (5). Finally, to the extent that the level of EPL for regular contracts and the level of temporary contracts affect firms decision on investment and, in turn, the level of capital affects labour productivity growth, we omit the capital-labour ratio and estimate a reduced form model to capture the overall effect on labour productivity growth:

$$
\begin{aligned}
\log y_{i j t}= & \alpha\left(\hat{\pi}_{j} * \sum_{k=1}^{t} E P L_{i k}\right)+\beta \sum_{k=1}^{t} E P L_{i k}+\gamma \sum_{k=1}^{t} T E_{i j k} \\
& +\sigma \sum_{k=1}^{t} X_{i j k}+\mu_{i}+\delta_{j}+\varphi_{t}+\varepsilon_{i j t}
\end{aligned}
$$

In what follows, Eq. (10) represents the baseline specification for the empirical analysis. We estimate different specifications of (10) to test the robustness of the results.

However, a potential drawback of specification (10) is that it produces consistent estimators under the strictly exogeneity of all covariates, which might not be the case in our empirical analysis. In particular, to the extent that hiring a temporary worker is a firm's decision, the share of TE might be endogenous in the labour productivity equation. For instance, as we argued previously the level of social and cultural capital is likely to represent a crucial factor driving cross-country differences on productivity. Nonetheless, it is difficult to account for it in the productivity equation and, consequently, the share of TE might be endogenous, as long as it is driven also by the time-varying social and cultural capital of a country.

Therefore, we perform also an IV-strategy, using the EPL index for TE as an instrument for the share of TE. In particular, the main idea here is that the country legislation concerning the use of temporary contracts certainly affects the share of TE in a country, like so the variation of the legislation affects the share over time. Differently, the legislation about TE should not have any impact on labour productivity but for the actual use of temporary contracts. In fact, as long as temporary contracts are not used in the labour market, a change in the legislation would be expected to have no impact on labour productivity. 
Hence, in the first stage we estimate the reduced form equation for the share of TE (11) including the EPL index for TE; then, in the second stage we estimate the model for labour productivity (12) using the fitted value $\widehat{T E}_{i j t}$ as the explanatory variable:

$$
\begin{aligned}
T E_{i j t}= & \zeta\left(\hat{\pi}_{j} * \sum_{k=1}^{t} E P L_{i k}^{P E}\right)+\varphi \sum_{k=1}^{t} E P L_{i k}^{P E}+\eta \sum_{k=1}^{t} E P L_{i j k}^{T E} \\
& +\psi \sum_{k=1}^{t} X_{i j k}+\mu_{i}+\delta_{j}+\varphi_{t}+\varepsilon_{i j t} \\
\log y_{i j t}= & \alpha\left(\hat{\pi}_{j} * \sum_{k=1}^{t} E P L_{i k}\right)+\beta \sum_{k=1}^{t} E P L_{i k}+\gamma \sum_{k=1}^{t} \widehat{T E}_{i j k} \\
& +\sigma \sum_{k=1}^{t} X_{i j k}+\mu_{i}+\delta_{j}+\varphi_{t}+\varepsilon_{i j t}
\end{aligned}
$$

To some extent, our specifications are similar to previous papers in this literature, with the crucial difference that while they use the same identification strategy for the two EPL indexes, we distinguish between EPL for PE and TE. Indeed, our IV-approach would seem fairly consistent, considering that the EPL index for TE can be considered exogenous in (10) and, furthermore, it is correlated with the share of TE once the other exogenous variables have been netted out. ${ }^{8}$ In our view, this different identification strategy for TE, which represents the main contribution of this paper to the literature, should allow us to capture more consistently the impact of TE on labour productivity.

As emphasized by the previous literature, the advantage of using a panel of industry-level data, instead of crosscountry, is fourfold. First, not only the cross-country variation of EPL is still exploited, but also the variation on the impact of EPL in different industries. And considering that the amount of variation in EPL index for PE across countries and years is indeed not so high, this advantage could be crucial in yielding the sufficient variation to identify the impact of EPL. Second, in contrast to the cross-country analysis, the specification allows us to control for unobserved fixed effects, allowed to be correlated with the other explanatory variables. Given the difficulty to control for all factors affecting labour productivity growth, this could be crucial to attenuate both omitted variable bias and misspecification. Third,

\footnotetext{
${ }^{8}$ As standard in the IV-procedure, while we can easily test for the second condition (partial correlation between instrument and instrumented in the reduced form equation), we cannot test for the exogeneity condition of our instrument. Nonetheless, on one hand in the literature this kind of instrument (index measuring the strictness of a legislation) tend to be considered strictly exogenous; on the other hand, our argument stated above on the inappropriateness of the direct use of the EPL index for TE as explanatory variable in the labour productivity equation leads us to consider fairly reliable also the exogeneity condition of our instrument.
}

as the previous literature emphasised (e.g. OECD 2007b), the within-industry "composition effect" appears to be negligible, allowing us to identify the "independent effect" of EPL for PE and TE. ${ }^{9}$ Fourth, to the extent that events in a single industry are not so relevant alone to affect the policy in a country, the specification is less subject to the simultaneity problem between the variable of interest and policy.

To some extent, a micro-level panel with establishment or linked employer-employee data might offer a research design even more appealing to evaluate the impact of some labour market policies as temporary contracts. In fact, it is well-recognised in the literature that microeconometric methods offer the highest degree of internal validity, intended as the validity of the causal inference based on the econometric analysis (e.g. Angrist and Pischke 2009). However, such datasets are usually bounded to a specific country (for instance, WHIP for Italy, LIAB for Germany, EPA for Spain, BHPS for England) and, therefore, do not allow to generalize the inference about the causal-effect relationship studied to other contexts and/or populations. In particular, as far as the evaluation of temporary contracts is concerned, there are studies using firm-level data, but in fact they tend to limit the validity of the causal inference only to the corresponding population (e.g. Boeri and Garibaldi 2007a). Differently, there are not studies performing microeconometric methods on firm-level data covering all European Countries. Thus, in the perspective to offer a reliable evaluation valid for the European context as a whole, the choice of the industry-level panel should represent a good compromise between the internal and external validity of the causal inference.

\subsection{Data}

The empirical analysis is performed on an industry-level panel of EU countries. ${ }^{10}$ The final sample covers 10 sectors

\footnotetext{
${ }^{9}$ In the literature the impact of a labour market policy on productivity is usually divided into "composition effect" and "independent effect". The first is the effect on productivity associated with the change in the composition of employment due to the policy variation (for instance, an increase in the share of unskilled workers). The second is the pure average effect of the policy on productivity (that is, ceteris paribus) and, thus, it is often the effect of interest. In this regard, different previous studies emphasize that "composition effects" are somewhat relevant in the aggregate analysis and, indeed, they cannot be easily dismissed. Therefore, any aggregate analysis of the impact of some labour market policies on productivity hardly will be able to isolate the "independent effect" of the policy and, in turn, to produce a useful contribution for policy guidance. Differently, industry-level analyses suggest that the within-industry "composition effects" are fairly negligible (OECD $2007 \mathrm{~b}$ ) and, therefore, the use of industry-level panel data should succeed in identifying the "independent effect" of the policy on productivity.

${ }^{10}$ At the beginning of the data collection the program comprised a wider dataset than the final one, including more countries as the United
} 
in 13 countries over the years 1992-2005, for a balanced panel of 1820 observations. ${ }^{11}$ Indeed, from the data analysis it appears evident that the final sample exhibits a sufficient amount of variation to reach the identification.

To collect our dataset we made use of different sources. The data on labour productivity and employment level at the industry-level were collected from EU KLEMS dataset. This comprehensive database contains data on economic growth, productivity, employment and other variables at the industry-level for all EU countries, providing an important data-source for policy evaluation. Moreover, productivity measures are developed with growth accounting techniques, coherently with our empirical specification.

The labour productivity measure used is the "gross value added per hour worked, volume indices, $1995=100$ ", corresponding to the variable $L P \_I$ in EU KLEMS database, that is

$y_{i j t}=\frac{(V A / L)_{i j t}}{(V A / L)_{i j 1995}} * 100$

where $V A$ is the gross value added in volumes and $L$ is the total amount of hours worked. A potential disadvantage of using an index measure with value added in volumes is that it limits the comparability in productivity levels between countries and industries. Nonetheless, in our econometric analysis we are interested in exploiting the variation in productivity growth between countries and industries, which indeed is entirely exploited using our measure (13). ${ }^{12}$ Furthermore, the productivity measure (13) has the advantage of being neutral to any difference in price dynamics between countries and industries. Finally, the index measure

States, Canada, Australia, a deeper segmentation across sectors and a more extensive time period. However, on one hand the need to include the share of TE as independent variable obligated us to reduce the time period and limit the sample to EU countries. On the other hand, the need to homogenize the sectors segmentation among different data-sources forced us to use the most comprehensive segmentation. In this regard, all data-sources follow the NACE classification, but not at the same level of aggregation. In particular, EUROSTAT data are segmented at the most extensive level of aggregation, therefore we aggregated all data at that level.

${ }^{11}$ Countries included in the sample are Austria, Belgium, Denmark, Finland, France, Germany, Ireland, Italy, the Netherlands, Portugal, Spain, Sweden and the United Kingdom. The final sectors segmentation satisfies the need of homogeneity among datasets and reflects the EUROSTAT segmentation, including "Agriculture, hunting and forestry", "Manufacturing", "Electricity, gas and water supply", "Construction", "Wholesale and retail trade", "Hotels and restaurants", "Transport, storage and communication", "Financial intermediation", "Real estate, renting and business activities", "Other community, social, personal service activities".

${ }^{12}$ In particular, the index measure (13) leads to a labour productivity growth as the unit measure of value added

$\frac{y_{i j k+1}-y_{i j k}}{y_{i j k}}=\frac{\frac{(V A / L)_{i j k+1}}{(V A / L)_{i j 1995}} * 100-\frac{(V A / L)_{i j k}}{(V A / L)_{i j 1995}} * 100}{\frac{(V A / L)_{i j k}}{(V A / L)_{i j 1995}} * 100}$ with value added in volumes is the productivity measure largely most used in the literature (e.g. OECD 2007a, 2007b; Bassanini et al. 2009), with the considerable advantage of making our study more comparable to previous results in the literature. Looking at the behaviour of our variable over time, the mean of labour productivity in the entire sample is 108.57 , whereas the mean omitting 1992-1993-1994 is 111.91, telling us that labour productivity grew from 1995 to 2005 in EU countries, even if not so significantly.

The data on employment level were used to construct the actual job reallocation rates, needed to obtain our measures of natural rate of job reallocation for each industry. While the estimated natural rates of job reallocation are contained in a restricted range (see Appendix 2), the actual job reallocation rates are much more changeable, going from 0.2388 to 0 . Indeed, this large difference would seem to confirm the criticism according to which actual job reallocation rates are significantly influenced by aggregate shocks, producing a short rather than a long-run measure of the natural need of job reallocation.

The shares of TE at the industry-level were constructed from EU-Labour Force Survey (LFS), a labour market survey providing annually and quarterly information about trends on the labour market in EU countries. For an object so heterogeneous like TE perfect comparability among countries is difficult to achieve, even by means of a single survey carried out at the same time, using the same questionnaire and a single method of recording. Nonetheless, the degree of comparability of the LFS results is considerably higher than that of any other existing set of statistics on employment available for countries in our sample. Given these institutional discrepancies, the LFS concept of TE describes situations which, in different institutional contexts, can be considered similar. ${ }^{13}$ In Appendix 1 we report a list of job types included in the LFS as temporary forms of employment. Despite it arguably should be the best measure of TE for our study, still there might be some potential problems in the implementation of such measure for identifying the effect of TE (see Appendix 3 for more details).

The mean and standard deviation of the share of TE in the sample are respectively 0.09 and 0.075 , confirming the idea that TE is an important feature of the labour market

$$
\begin{aligned}
& =\frac{\frac{100}{(V A / L)_{i j 1995}}\left((V A / L)_{i j k+1}-(V A / L)_{i j k}\right)}{\frac{(V A / L)_{i j k}}{(V A / L)_{i j 1995}} * 100} \\
& =\frac{(V A / L)_{i j k+1}-(V A / L)_{i j k}}{(V A / L)_{i j k}}
\end{aligned}
$$

which is entirely comparable between countries and industries.

${ }^{13}$ The EUROSTAT definition of temporary contracts is the following: "Employees with temporary contracts are those who declare themselves as having a fixed term employment contract or a job which will terminate if certain objective criteria are met, such as completion of an assignment or return of the employee who was temporarily replaced". 
landscape in Europe by this time, but its importance differs significantly across countries. For instance, while in countries as Spain and Portugal the share of TE is far away from the mean, in the UK the mean is no more than 0.05 (see Table 10). Among different sectors, those using on average more temporary contracts are not surprisingly "Hotels and restaurants" and "Construction", instead the industries using less are "Electricity, gas and water supply" and "Financial intermediation" (see Table 9).

As measure of EPL for PE we made use of the cardinal index constructed by OECD (2004), varying in theory from 6 for the most stringent to 0 for the least stringent regulation. The time-series for the EPL indexes have been recently updated and now are available until 2007. ${ }^{14}$ In our sample from 1992 to 2005 the EPL index for PE ranges from 4.33 in Portugal (1992-2003) to 0.95 in the UK (1992-1999). The mean of the index follows a slightly decreasing trend, going from 2.46 at the beginning of the sample 1992, to 2.31 at the end 2005. However, the decreasing trend in the stringency of regulation of PE is far from being common to all countries, rather it seems to be driven by changes in Spain and Portugal.

The EPL index for TE ranges from 5.38 in Italy (19921996) to 0.25 in the UK (1992-2001). Similarly to PE, the mean of the index for TE follows a decreasing trend, going from 2.92 in 1992 to 1.92 in 2005. But differently to PE, the decreasing trend seems to be a common feature in fairly all EU countries.

Unfortunately no data on trade union density at industrylevel are available, therefore they were collected at countrylevel from OECD—Labour Force Statistics. The mean in the sample is 0.41 , telling us how trade union are still an important subject in Europe. However, the standard deviation of 0.23 suggests how different is its importance across EU countries. In the sample trade union density ranges from 0.84 in Sweden (1993) to 0.08 in France (2005).

A full description of all variables and sources can be found in Appendix 1, whereas descriptive statistics are in Appendix 2 (see Table 8).

\section{Results}

In this section we discuss the main results of the empirical analysis, along with some robustness checks. First, we present the results of the baseline specifications, with and without the interaction of the share of PE with the EPL index. Then, we provide some sensitive analysis to check if our findings are robust to little changes in the specification

\footnotetext{
${ }^{14}$ See the "fRDB-IZA Social Reforms Database" on www.frdb.org for more details.
}

and sample. Finally, to show the advantage of our identification strategy respect to previous literature, we re-estimate the model using the EPL index for TE instead of the share of TE as independent variable.

\subsection{Baseline specification}

In Table 1 are the coefficients of different specifications, along with robust standard errors and some other relevant statistics. In the first column, related to a simple POLS regression, the point estimates of EPL*FJR and TE are negative, the coefficient of TE is significant at $1 \%$, whereas that of EPL*FJR is significant at $10 \%$. While these estimates are useful to get an insight on the direction of the effect, they cannot be interpreted as causal impact, given the omitted variable bias and the potential endogeneity of TE. In the following two columns we report the estimates respectively from FD and FE regression. In particular, in (3) we include country, sector and time fixed effects to control for institutional, technological and time differentials. As expected, the two specifications produce point estimates very similar, but FD turns out to produce estimate with very little precision. In both specifications the coefficients of EPL*FJR and TE are negative, the coefficient of TE is significant at $1 \%$, whereas that of EPL*FJR is significant only in (3). Finally, in (4) and (5) we report the estimates of our IV-strategy described above, along with the result of the endogeneity test of the share of TE. In particular, we find that both the coefficients of EPL*FJR and TE are negative and significant at $1 \%$. Furthermore, the R-squared values in FE regressions are significantly higher than POLS and FD. ${ }^{15}$ Moreover, the result of the endogeneity test seems to confirm that the share of TE is, indeed, endogenous in the labour productivity equation. Therefore, the estimates of the simple FE regression turn out to be biased and, in particular, the coefficient of the share of TE would seem to underestimate the negative impact of TE.

Since we are able to control for several unobserved factors, as well as for the endogeneity of the share of TE, we interpret these results as causal impact of EPL and TE on labour productivity growth. The magnitude of the coefficient of TE is about -0.26 , implying that an increase of 10 percentage points of the share of temporary contracts would lead to a decrease of about $2-3 \%$ in labour productivity. Furthermore, the coefficient of EPL*FJR is sizably greater

\footnotetext{
${ }^{15}$ The extremely high values of R-squared in FE are probably due to the inclusion of the large set of dummies (country, sector and time fixed effects) in our FE regressions. Therefore, such high explanatory power should be largely ascribed to fixed effects, which indeed we can interpret just as general institutional, technological and time factors driving productivity differentials. Nonetheless, their inclusion should help us to alleviate significantly the omitted variable bias and, consequently, to isolate the impact of our variables of interest (EPL and TE).
} 
Table 1 Labour productivity (without PE)

\begin{tabular}{|c|c|c|c|c|c|}
\hline & $\begin{array}{l}\text { (1) } \\
\text { POLS }\end{array}$ & $\begin{array}{l}(2) \\
\text { FD }\end{array}$ & $\begin{array}{l}\text { (3) } \\
\text { FE }\end{array}$ & $\begin{array}{l}(4) \\
\text { IV-FD }\end{array}$ & $\begin{array}{l}\text { (5) } \\
\text { IV-FE }^{b}\end{array}$ \\
\hline EPL & $\begin{array}{l}0.004 \\
(0.001)^{* * *}\end{array}$ & $\begin{array}{l}0.005 \\
(0.002)^{*}\end{array}$ & $\begin{array}{l}0.005 \\
(0.002)^{* *}\end{array}$ & $\begin{array}{l}0.010 \\
(0.005)^{* *}\end{array}$ & $\begin{array}{l}0.011 \\
(0.003)^{\text {*** }}\end{array}$ \\
\hline EPL*FJR & $\begin{array}{l}-0.048 \\
(0.026)^{*}\end{array}$ & $\begin{array}{l}-0.077 \\
(0.053)\end{array}$ & $\begin{array}{l}-0.076 \\
(0.040)^{*}\end{array}$ & $\begin{array}{l}-0.122 \\
(0.062)^{* *}\end{array}$ & $\begin{array}{l}-0.138 \\
(0.044)^{\text {*** }}\end{array}$ \\
\hline $\mathrm{TE}$ & $\begin{array}{l}-0.100 \\
(0.007)^{* * *}\end{array}$ & $\begin{array}{l}-0.124 \\
(0.018)^{* * *}\end{array}$ & $\begin{array}{l}-0.081 \\
(0.009)^{* * *}\end{array}$ & $\begin{array}{l}-0.260 \\
(0.093)^{* * *}\end{array}$ & $\begin{array}{l}-0.263 \\
(0.070)^{\text {*** }}\end{array}$ \\
\hline TUD & $\begin{array}{l}-0.001 \\
(0.000)^{* * *}\end{array}$ & $\begin{array}{l}-0.002 \\
(0.001)^{* *}\end{array}$ & $\begin{array}{l}-0.002 \\
(0.002)\end{array}$ & $\begin{array}{l}-0.003 \\
(0.001)^{* *}\end{array}$ & $\begin{array}{l}-0.001 \\
(0.000)^{* *}\end{array}$ \\
\hline Trend & $\begin{array}{l}0.024 \\
(0.002)^{* * *}\end{array}$ & & $\begin{array}{l}0.354 \\
(0.012)^{* * *}\end{array}$ & & $\begin{array}{l}0.032 \\
(0.027)\end{array}$ \\
\hline Constant & $\begin{array}{l}4.554 \\
(0.008)^{* * *}\end{array}$ & $\begin{array}{l}0.028 \\
(0.004)^{* * *}\end{array}$ & & $\begin{array}{l}0.030 \\
(0.007)^{* * *}\end{array}$ & \\
\hline Sector dummies & NO & NO & YES & NO & YES \\
\hline Country dummies & NO & NO & YES & NO & YES \\
\hline Year dummies & NO & YES & YES & YES & YES \\
\hline Endogeneity Test ${ }^{\mathrm{a}}$ & & & & $p-v a l=0.127$ & $p-v a l=0.004$ \\
\hline Observations & 1820 & 1690 & 1820 & 1690 & 1820 \\
\hline R-squared & 0.3079 & 0.1157 & 0.9993 & 0.1231 & 0.9991 \\
\hline
\end{tabular}

POLS: pooled ordinary least squares; FD: first difference; FE: fixed effects (dummy variable regression); IV: instrumental variables (two stage least squares); EPL: employment protection legislation; FJR: frictionless job reallocation; TE: the share of temporary employment; TUD: trade union density

HAC Robust standard errors in brackets. ${ }^{*}$ significant at $10 \%,{ }^{* *}$ significant at $5 \%,{ }^{* * *}$ significant at $1 \%$

${ }^{a}$ The endogeneity test is the difference of two Sargan-Hansen statistics: one for the equation with the smaller set of instruments and one for the equation with the larger set of instruments. Unlike the Hausman tests, this statistic is robust to heteroskedasticity and serial correlation. ${ }^{b}$ First-stage estimates reported in Table 11

than that of EPL, implying that EPL for regular contracts reduce labour productivity growth more in those industries requiring a greater reallocation.

To the extent that firing restrictions affect the behaviour of only permanent workers, in Table 2 we try to interact the EPL index for PE with the share of permanent workers $\mathrm{PE}(=1-\mathrm{TE})$. Indeed, the results are qualitatively similar to those of Table 1, but as expected the coefficients of EPL*FJR are greater in all specifications.

\subsection{Robustness checks}

In what follows, we provide some sensitive analysis to check the robustness of our findings. Despite we maintain the method proposed by Ciccone and Papaioannou (2006) as the main source of our interpretation, we re-estimate the model using a binding/non-binding approach. Following the previous empirical literature, we make use of job reallocation rates in the US to divide between binding (B) and nonbinding industries (NB). We estimate the model with two different binary indicators (BI).

For the first BI1 an industry is B if the job reallocation rate in the US is greater than the average for at least two of the three years 2001-2002-2003. According to BI1, the following four industries are B: "Manufacturing", "Transport, storage and communication", "Real estate, renting and business activities", "Other community, social, personal service activities". The second BI is slightly less demanding. For BI2 an industry is B if the job reallocation rate in the US is greater than the average for at least two of the four years 2001-2002-2003-2004. According to BI2, the following five industries are B: "Agriculture, hunting and forestry", "Manufacturing", "Transport, storage and communication", "Real estate, renting and business activities", "Other community, social, personal service activities".

In Table 3 are the results of BI1 model. The coefficients of the share of TE are all negative, significant at $1 \%$ and very close to the point estimates in Table 1 . The coefficients of EPL*BI1 are also negative and significant, but as expected the magnitude is significantly different from the FJR specifications. However, the magnitude is fairly equal to the binding/non-binding specification of Bassanini and Venn (2007) and Bassanini et al. (2009). In fact, apparently the BI approach in those papers produce a very similar classification in terms of B and NB sectors. In Table 4 we estimate the 
Table 2 Labour productivity (with PE)

\begin{tabular}{|c|c|c|c|c|c|}
\hline & $\begin{array}{l}(1) \\
\text { POLS }\end{array}$ & $\begin{array}{l}(2) \\
\text { FD }\end{array}$ & $\begin{array}{l}\text { (3) } \\
\text { FE }\end{array}$ & $\begin{array}{l}\text { (4) } \\
\text { IV-FD }\end{array}$ & $\begin{array}{l}\text { (5) } \\
\text { IV-FE }\end{array}$ \\
\hline EPL*PE & $\begin{array}{l}0.004 \\
(0.001)^{* * *}\end{array}$ & $\begin{array}{l}0.005 \\
(0.003)^{*}\end{array}$ & $\begin{array}{l}0.006 \\
(0.002)^{* *}\end{array}$ & $\begin{array}{l}0.007 \\
(0.003)^{* *}\end{array}$ & $\begin{array}{l}0.006 \\
(0.002)^{* * *}\end{array}$ \\
\hline EPL*FJR*PE & $\begin{array}{l}-0.049 \\
(0.028)^{*}\end{array}$ & $\begin{array}{l}-0.079 \\
(0.058)\end{array}$ & $\begin{array}{l}-0.089 \\
(0.046)^{*}\end{array}$ & $\begin{array}{l}-0.118 \\
(0.061)^{* *}\end{array}$ & $\begin{array}{l}-0.139 \\
(0.047)^{* * *}\end{array}$ \\
\hline TE & $\begin{array}{l}-0.096 \\
(0.006)^{* * *}\end{array}$ & $\begin{array}{l}-0.120 \\
(0.017)^{* * *}\end{array}$ & $\begin{array}{l}-0.077 \\
(0.008)^{* * *}\end{array}$ & $\begin{array}{l}-0.214 \\
(0.065)^{* * *}\end{array}$ & $\begin{array}{l}-0.192 \\
(0.041)^{* * *}\end{array}$ \\
\hline TUD & $\begin{array}{l}-0.001 \\
(0.000)^{* * *}\end{array}$ & $\begin{array}{l}-0.002 \\
(0.001)^{* *}\end{array}$ & $\begin{array}{l}-0.002 \\
(0.002)\end{array}$ & $\begin{array}{l}-0.003 \\
(0.003)\end{array}$ & $\begin{array}{l}-0.001 \\
(0.000)^{* *}\end{array}$ \\
\hline Trend & $\begin{array}{l}0.024 \\
(0.002)^{* * *}\end{array}$ & & $\begin{array}{l}0.353 \\
(0.012)^{* * *}\end{array}$ & & $\begin{array}{l}0.037 \\
(0.026)\end{array}$ \\
\hline Constant & $\begin{array}{l}4.554 \\
(0.008)^{* * *}\end{array}$ & $\begin{array}{l}0.028 \\
(0.004)^{* * *}\end{array}$ & & $\begin{array}{l}0.033 \\
(0.009)^{* * *}\end{array}$ & \\
\hline Sector Dummies & NO & NO & YES & NO & YES \\
\hline Country Dummies & NO & NO & YES & NO & YES \\
\hline Year Dummies & NO & YES & YES & YES & YES \\
\hline Endogeneity Test ${ }^{\mathrm{a}}$ & & & & $p-v a l=0.124$ & $p$-val $=0.003$ \\
\hline Observations & 1820 & 1690 & 1820 & 1690 & 1820 \\
\hline R-squared & 0.3077 & 0.1156 & 0.9993 & 0.1373 & 0.9992 \\
\hline
\end{tabular}

POLS: pooled ordinary least squares; FD: first difference; FE: fixed effects (dummy variable regression); IV: instrumental variables (two stage least squares); EPL: employment protection legislation; FJR: frictionless job reallocation; TE: the share of temporary employment; PE: the share of permanent employment; TUD: trade union density

HAC Robust standard errors in brackets. ${ }^{*}$ significant at $10 \%,{ }^{* *}$ significant at $5 \%,{ }^{* * *}$ significant at $1 \%$

${ }^{a}$ The endogeneity test is the difference of two Sargan-Hansen statistics: one for the equation with the smaller set of instruments and one for the equation with the larger set of instruments. Unlike the Hausman tests, this statistic is robust to heteroskedasticity and serial correlation. ${ }^{b}$ First-stage estimates reported in Table 11

model with BI2. As can be easily seen, the results are very close to the BI1, with the only difference that the coefficients of EPL*BI2 are slightly less significant, probably as a consequence of a lower identification power of the second BI. In summary, using the binding/non-binding approach does not seem to alter the results of the analysis.

To check if the baseline results depend crucially on the inclusion of some countries in the sample, we re-estimate the model excluding all countries one-by-one. In particular, we run many FE regressions equal to specifications (3) and (5) in Table 1, but using a reduced sample. In Tables 5 and 6 are the complete results of the 26 regressions, whereas in the Fig. 3 are the coefficients of the share of TE, arranged from the greatest to the smallest, for both FE and IV.

Evidently, the baseline outcome does not depend on the sample of countries included in the empirical analysis. Indeed, the coefficients of the share of TE are always negative and significant at $1 \%$ regardless of the sample used. Furthermore, the magnitude of the coefficients would seem to validate sufficiently our result that an increase of 10 percentage points of the share of temporary contracts would lead to a decrease of about $2-3 \%$ in labour productivity. Similarly,

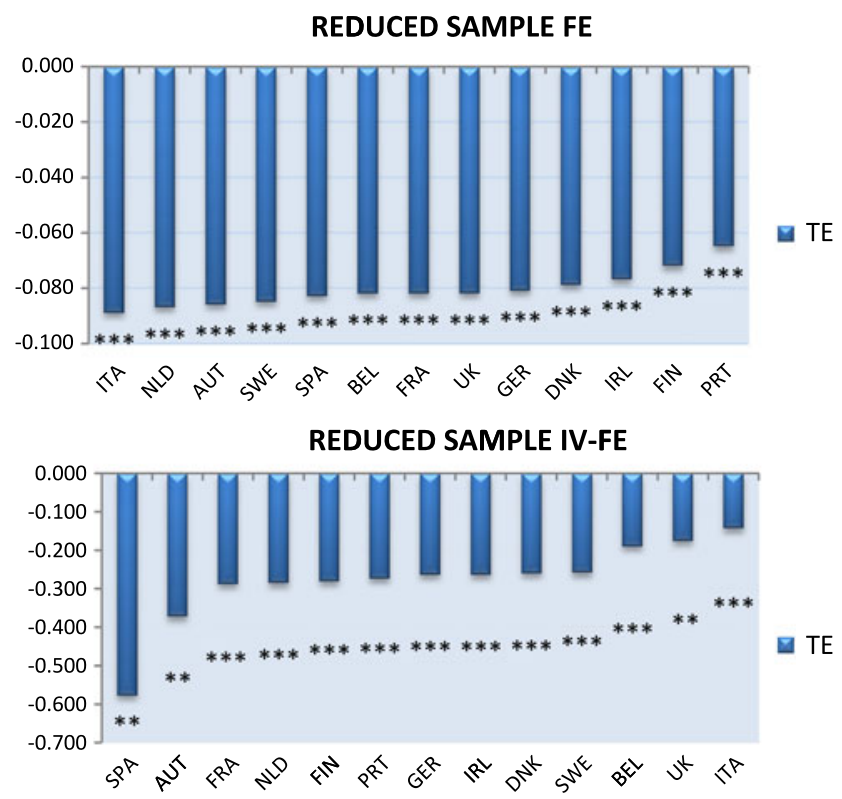

Fig. 3 Coefficients of TE from the reduced sample estimates 
Table 3 Labour productivity (with BI1)

\begin{tabular}{|c|c|c|c|c|c|}
\hline & $\begin{array}{l}\text { (1) } \\
\text { POLS }\end{array}$ & $\begin{array}{l}\text { (2) } \\
\text { FD }\end{array}$ & $\begin{array}{l}\text { (3) } \\
\text { FE }\end{array}$ & $\begin{array}{l}\text { (4) } \\
\text { IV-FD }\end{array}$ & $\begin{array}{l}\text { (5) } \\
\text { IV-FE }^{b}\end{array}$ \\
\hline EPL & $\begin{array}{l}0.002 \\
(0.001)^{* *}\end{array}$ & $\begin{array}{l}0.002 \\
(0.002)^{*}\end{array}$ & $\begin{array}{l}0.002 \\
(0.001)^{*}\end{array}$ & $\begin{array}{l}0.004 \\
(0.002)^{*}\end{array}$ & $\begin{array}{l}0.006 \\
(0.002)^{* * *}\end{array}$ \\
\hline EPL*BI1 & $\begin{array}{l}-0.002 \\
(0.000)^{* * *}\end{array}$ & $\begin{array}{l}-0.002 \\
(0.001)^{* *}\end{array}$ & $\begin{array}{l}-0.002 \\
(0.000)^{* * *}\end{array}$ & $\begin{array}{l}-0.002 \\
(0.001)^{*}\end{array}$ & $\begin{array}{l}-0.002 \\
(0.001)^{* *}\end{array}$ \\
\hline $\mathrm{TE}$ & $\begin{array}{l}-0.096 \\
(0.006)^{* * *}\end{array}$ & $\begin{array}{l}-0.116 \\
(0.018)^{* * *}\end{array}$ & $\begin{array}{l}-0.075 \\
(0.008)^{* * *}\end{array}$ & $\begin{array}{l}-0.203 \\
(0.115)^{*}\end{array}$ & $\begin{array}{l}-0.263 \\
(0.070)^{* * *}\end{array}$ \\
\hline TUD & $\begin{array}{l}-0.001 \\
(0.000)^{* * *}\end{array}$ & $\begin{array}{l}-0.001 \\
(0.000)\end{array}$ & $\begin{array}{l}-0.002 \\
(0.002)\end{array}$ & $\begin{array}{l}-0.001 \\
(0.000)\end{array}$ & $\begin{array}{l}-0.001 \\
(0.000)^{* *}\end{array}$ \\
\hline Trend & $\begin{array}{l}0.028 \\
(0.002)^{* * *}\end{array}$ & & $\begin{array}{l}0.356 \\
(0.012)^{* * *}\end{array}$ & & $\begin{array}{l}0.032 \\
(0.027)\end{array}$ \\
\hline Constant & $\begin{array}{l}4.521 \\
(0.007)^{* * *}\end{array}$ & $\begin{array}{l}0.021 \\
(0.006)^{* * *}\end{array}$ & & $\begin{array}{l}0.027 \\
(0.011)^{* *}\end{array}$ & \\
\hline Sector dummies & NO & $\mathrm{NO}$ & YES & NO & YES \\
\hline Country dummies & NO & NO & YES & NO & YES \\
\hline Year dummies & NO & YES & YES & YES & YES \\
\hline Endogeneity Test ${ }^{\mathrm{a}}$ & & & & $p-v a l=0.435$ & $p-v a l=0.003$ \\
\hline Observations & 1820 & 1690 & 1820 & 1690 & 1820 \\
\hline R-squared & 0.3126 & 0.1517 & 0.9993 & 0.1395 & 0.9991 \\
\hline
\end{tabular}

POLS: pooled ordinary least squares; FD: first difference; FE: fixed effects (dummy variable regression); IV: instrumental variables (two stage least squares); EPL: employment protection legislation; BI1: binary indicator 1; TE: the share of temporary employment; TUD: trade union density HAC Robust standard errors in brackets. ${ }^{*}$ significant at $10 \%,{ }^{* *}$ significant at $5 \%$, ${ }^{* * *}$ significant at $1 \%$

${ }^{\text {a }}$ The endogeneity test is the difference of two Sargan-Hansen statistics: one for the equation with the smaller set of instruments and one for the equation with the larger set of instruments. Unlike the Hausman tests, this statistic is robust to heteroskedasticity and serial correlation. ${ }^{\mathrm{b}}$ First-stage estimates reported in Table 11

endogeneity tests from the reduced sample tend to confirm the endogeneity of TE.

In conclusion, our findings of a negative impact of both EPL for PE and the share of TE on labour productivity growth appear to be fairly robust to little changes in the estimation approach and in the sample of countries included in the analysis.

\subsection{EPL index for TE vs the share of TE}

In order to show the advantage of our identification strategy respect to previous literature, we re-estimate the model using the EPL index for TE instead of the share of TE as independent variable. In Table 7 are the results of the estimation exercise.

Consistently with our view, the use of the same strategy for PE and TE would seem to have reduced significantly the identification power of the empirical analysis. Although we use the same specifications and sample of Table 1, the coefficients of EPL for TE*FJR are always insignificant and those of EPL for TE are apparently estimated with lower precision. Moreover, despite the point estimates of EPL for $\mathrm{PE}$ and EPL*FJR remain in line with our baseline estimates, they become always insignificant, which would be heavily in contrast to standard findings of previous papers in the literature. Our interpretation of this finding is that, once we exclude the share of TE from the explanatory variables, the coefficient of the EPL for PE should pick up also the impact of TE. To some extent, this interpretation would seem strongly corroborated on one hand by the standard view in the literature that high EPL for regular contracts would be one of the main explanation of the rapid growth of TE in EU countries; on the other hand, by our first-stage estimates (see Appendix 2) in the IV-approach (11), confirming that there would be a strong positive correlation between the EPL for PE and the share of TE.

In conclusion, for the theoretical reasons discussed above, the identification strategy for PE does not appear to be appropriate for the identification of the effect of TE on labour productivity growth. Indeed, the empirical comparison between the use of the share of TE and the EPL index for TE seems to confirm the theoretical drawbacks highlighted in the paper. In particular, provided that one controls for the potential endogeneity bias, our analysis suggests a clear preference for the use of the share of TE. 
Table 4 Labour productivity (with BI2)

\begin{tabular}{|c|c|c|c|c|c|}
\hline & $\begin{array}{l}\text { (1) } \\
\text { POLS }\end{array}$ & $\begin{array}{l}(2) \\
\text { FD }\end{array}$ & $\begin{array}{l}\text { (3) } \\
\text { FE }\end{array}$ & $\begin{array}{l}(4) \\
\text { IV-FD }\end{array}$ & $\begin{array}{l}(5) \\
\text { IV-FE }\end{array}$ \\
\hline EPL & $\begin{array}{l}0.002 \\
(0.001)^{* *}\end{array}$ & $\begin{array}{l}0.002 \\
(0.002)^{*}\end{array}$ & $\begin{array}{l}0.002 \\
(0.001)^{*}\end{array}$ & $\begin{array}{l}0.004 \\
(0.003)\end{array}$ & $\begin{array}{l}0.006 \\
(0.002)^{* * *}\end{array}$ \\
\hline $\mathrm{EPL} * \mathrm{BI} 2$ & $\begin{array}{l}-0.001 \\
(0.000)^{*}\end{array}$ & $\begin{array}{l}-0.001 \\
(0.001)\end{array}$ & $\begin{array}{l}-0.002 \\
(0.001)^{* *}\end{array}$ & $\begin{array}{l}-0.001 \\
(0.001)\end{array}$ & $\begin{array}{l}-0.001 \\
(0.001)^{*}\end{array}$ \\
\hline TE & $\begin{array}{l}-0.098 \\
(0.007)^{* * *}\end{array}$ & $\begin{array}{l}-0.119 \\
(0.017)^{* * *}\end{array}$ & $\begin{array}{l}-0.080 \\
(0.009)^{* * *}\end{array}$ & $\begin{array}{l}-0.203 \\
(0.115)^{*}\end{array}$ & $\begin{array}{l}-0.263 \\
(0.071)^{* * *}\end{array}$ \\
\hline TUD & $\begin{array}{l}-0.001 \\
(0.000)^{* * *}\end{array}$ & $\begin{array}{l}-0.001 \\
(0.000)\end{array}$ & $\begin{array}{l}-0.001 \\
(0.000)\end{array}$ & $\begin{array}{l}-0.001 \\
(0.000)\end{array}$ & $\begin{array}{l}-0.001 \\
(0.000)^{*}\end{array}$ \\
\hline Trend & $\begin{array}{l}0.028 \\
(0.002)^{* * *}\end{array}$ & & $\begin{array}{l}0.352 \\
(0.004)^{* * *}\end{array}$ & & $\begin{array}{l}0.032 \\
(0.027)\end{array}$ \\
\hline Constant & $\begin{array}{l}4.521 \\
(0.006)^{* * *}\end{array}$ & $\begin{array}{l}0.021 \\
(0.006)^{* * *}\end{array}$ & & $\begin{array}{l}0.027 \\
(0.011)^{* *}\end{array}$ & \\
\hline Sector dummies & NO & NO & YES & NO & YES \\
\hline Country dummies & NO & NO & YES & NO & YES \\
\hline Year dummies & NO & YES & YES & YES & YES \\
\hline Endogeneity Test ${ }^{\mathrm{a}}$ & & & & $p-v a l=0.451$ & $p-v a l=0.003$ \\
\hline Observations & 1820 & 1690 & 1820 & 1690 & 1820 \\
\hline R-squared & 0.3056 & 0.1496 & 0.9993 & 0.1381 & 0.9991 \\
\hline
\end{tabular}

POLS: pooled ordinary least squares; FD: first difference; FE: fixed effects (dummy variable regression); IV: instrumental variables (two stage least squares); EPL: employment protection legislation; BI1: binary indicator 1; TE: the share of temporary employment; TUD: trade union density HAC Robust standard errors in brackets. ${ }^{*}$ significant at $10 \%,{ }^{* *}$ significant at $5 \%$, ${ }^{* * *}$ significant at $1 \%$

${ }^{\text {a }}$ The endogeneity test is the difference of two Sargan-Hansen statistics: one for the equation with the smaller set of instruments and one for the equation with the larger set of instruments. Unlike the Hausman tests, this statistic is robust to heteroskedasticity and serial correlation. ${ }^{\mathrm{b}}$ First-stage estimates reported in Table 11

\section{Policy implications and final remarks}

In this paper we have implemented a well-know method to evaluate the impact of partial labour market reforms in EU countries. Using an industry-level panel we are able to control for unobserved confounding factors, which should allow us to identify the causal impact of both regulation for PE and TE on labour productivity growth. Differently from the previous literature, in this paper we distinguish the identification strategy between the impact of firing restrictions for $\mathrm{PE}$ and the impact of the use of TE, underlining theoretical reasons to make this distinction. Comparing the model with the share of TE to that with the EPL index for TE, we have showed as the first improves significantly the identification power of the empirical analysis. For this reason, the empirical strategy presented in this paper would go to improve the previous empirical literature on the evaluation of this policy.

The main finding of the paper is that the use of temporary contracts has a negative impact on labour productivity growth. In particular, an increase of 10 percentage points of the share of TE would lead to a decrease of about 2-3\% in labour productivity. Furthermore, the analysis confirms the findings of the previous literature that EPL for regular contracts reduce labour productivity growth more in those industries requiring for their own characteristics a greater reallocation.

However, in our interpretation the increase of TE should not be considered a priori a negative labour market outcome; rather, the important issue here is what role TE is playing in the labour market. Indeed, if temporary contracts were used as a least-cost way of screening new workers and/or as a stepping stone towards more stable jobs, then an increase in the share of TE and its effect on productivity growth could be significantly different. The problem is that, as emphasised by a growing literature (e.g. Ichino et al. 2005, for Italy, Guell and Petrongolo 2007, for Spain, Kvasnicka 2008, for Germany and, more generally, OECD 2002, for European Countries), only one-third of temporary workers moves to a more stable job within two years, whereas one-fourth of them becomes unemployed one year later and a large part remains steadily in temporary jobs. Therefore, the negative impact of the increase of TE in Europe on productivity growth cannot be considered a short-run problem, but a dangerous structural change with long-run effects.

In the light of the predominant role of labour productivity growth in driving GDP growth, our findings are much rele- 


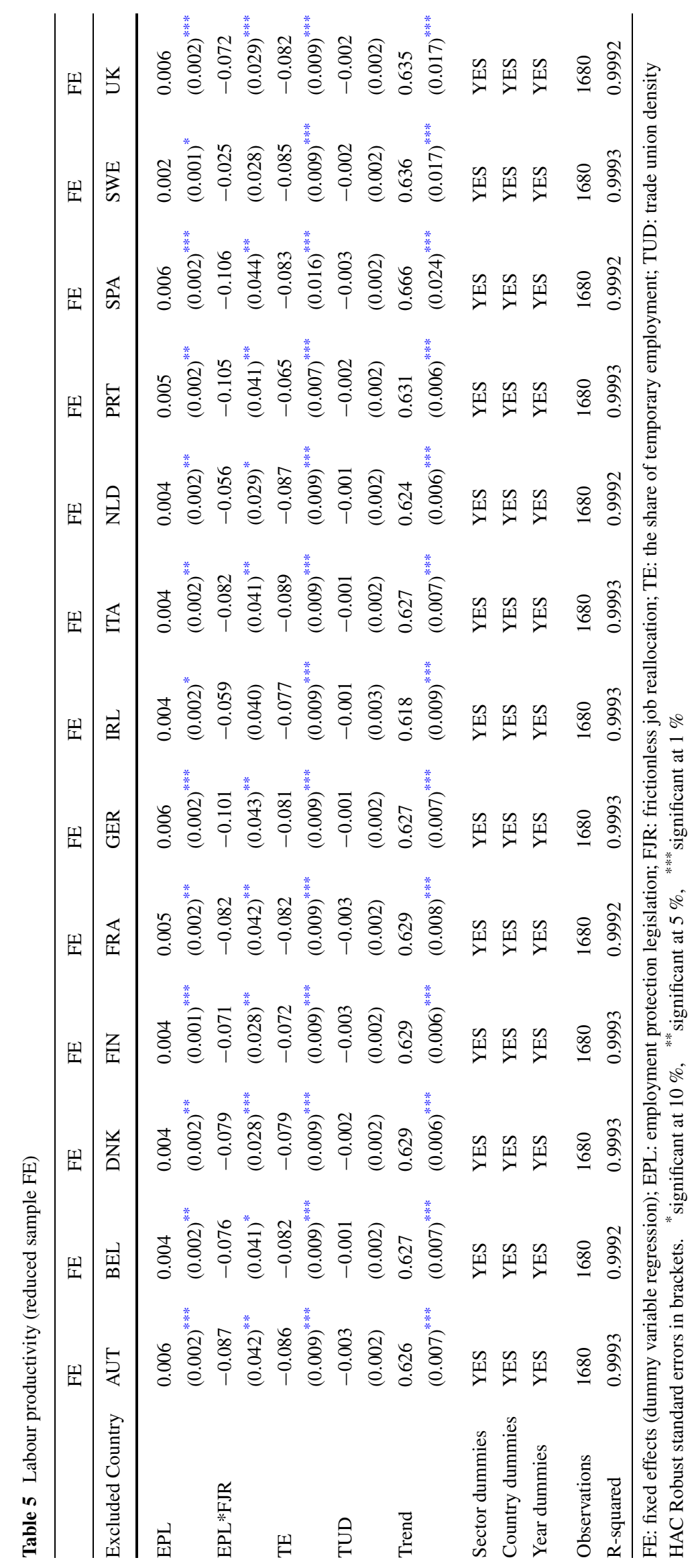




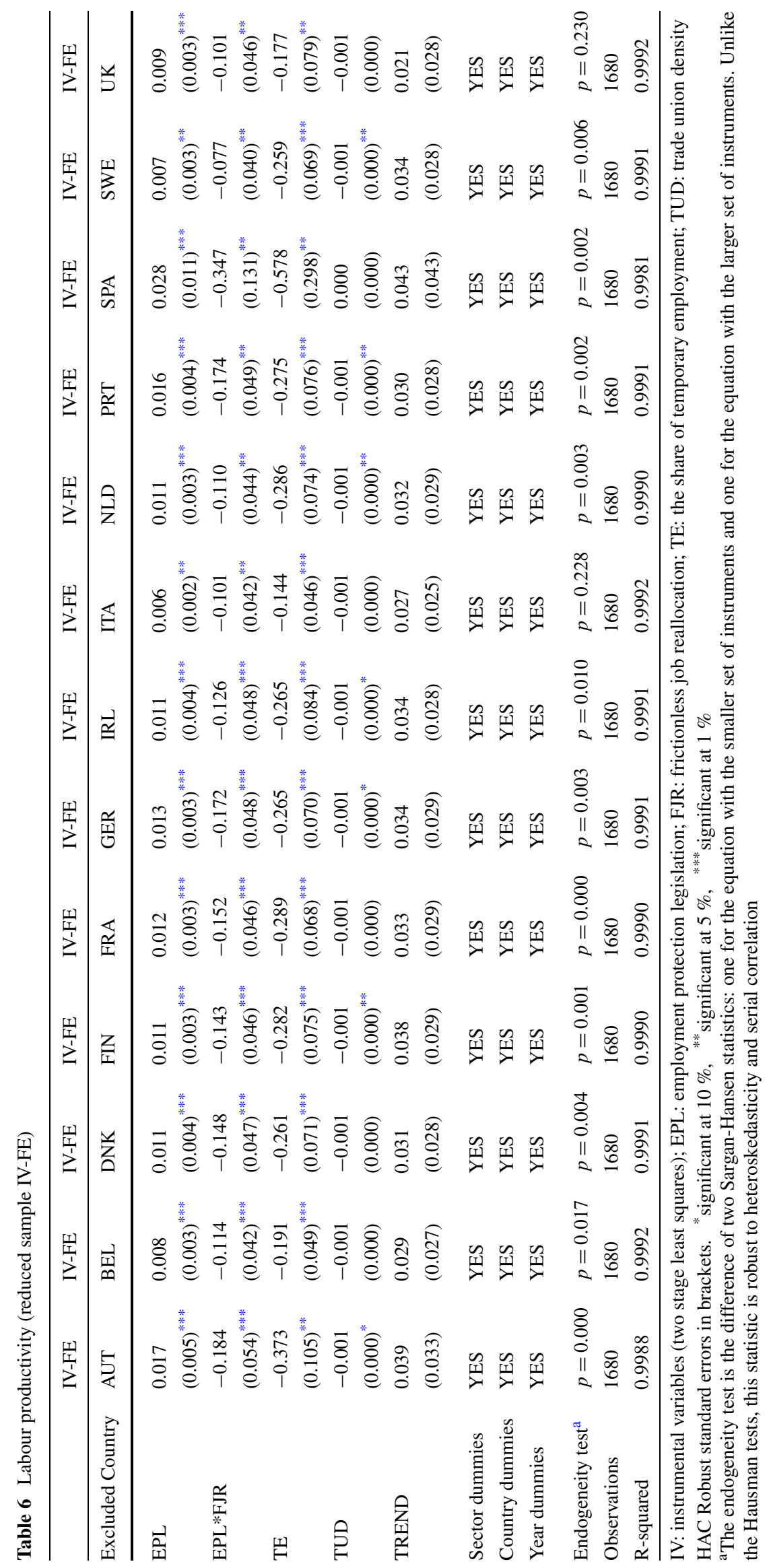


Table 7 Labour productivity (with EPL for TE)
POLS: pooled ordinary least squares; FD: first difference; FE: fixed effects (dummy variable regression); EPL: employment protection legislation; FJR: frictionless job reallocation; TUD: trade union density

HAC Robust standard errors in brackets. * significant at $10 \%$, ${ }^{* *}$ significant at $5 \%$, *** significant at $1 \%$

\begin{tabular}{|c|c|c|c|}
\hline & $\begin{array}{l}\text { (1) } \\
\text { POLS }\end{array}$ & $\begin{array}{l}(2) \\
\text { FD }\end{array}$ & $\begin{array}{l}(3) \\
\text { FE }\end{array}$ \\
\hline EPL for PE & $\begin{array}{l}0.003 \\
(0.002)\end{array}$ & $\begin{array}{l}0.004 \\
(0.005)\end{array}$ & $\begin{array}{l}0.004 \\
(0.003)\end{array}$ \\
\hline EPL for PE*FJR & $\begin{array}{l}-0.056 \\
(0.057)\end{array}$ & $\begin{array}{l}-0.103 \\
(0.121)\end{array}$ & $\begin{array}{l}-0.073 \\
(0.054)\end{array}$ \\
\hline EPL for TE & $\begin{array}{l}-0.004 \\
(0.002)^{* *}\end{array}$ & $\begin{array}{l}-0.005 \\
(0.005)\end{array}$ & $\begin{array}{l}-0.005 \\
(0.002)^{* *}\end{array}$ \\
\hline EPL for TE*FJR & $\begin{array}{l}0.042 \\
(0.046)\end{array}$ & $\begin{array}{l}0.076 \\
(0.113)\end{array}$ & $\begin{array}{l}0.033 \\
(0.035)\end{array}$ \\
\hline TUD & $\begin{array}{l}-0.001 \\
(0.000)^{* *}\end{array}$ & $\begin{array}{l}-0.001 \\
(0.000)\end{array}$ & $\begin{array}{l}-0.001 \\
(0.001)\end{array}$ \\
\hline Trend & $\begin{array}{l}0.025 \\
(0.002)^{* * *}\end{array}$ & & $\begin{array}{l}0.026 \\
(0.004)^{* * *}\end{array}$ \\
\hline Constant & $\begin{array}{l}4.535 \\
(0.006)^{* * *}\end{array}$ & $\begin{array}{l}0.016 \\
(0.006)^{* *}\end{array}$ & \\
\hline Sector dummies & NO & NO & YES \\
\hline Country dummies & NO & NO & YES \\
\hline Year dummies & NO & YES & YES \\
\hline Observations & 1820 & 1690 & 1820 \\
\hline R-squared & 0.2275 & 0.1289 & 0.9992 \\
\hline
\end{tabular}

vant and full of policy implications. In particular, the partial labour market reforms made by the majority of EU countries do not seem to correspond to the optimal way to organize labour market regulation.

The aim of the liberalization of TE was to generate a higher level of employment, removing the disincentive to hire intrinsic in a labour market with permanent contracts and layoff restrictions. And it is certainly true that the introduction of less stringent regulations has initially driven the employment growth. However, it is not clear as this expansion could be considered structural or just a honeymoon effect. Indeed, if the expansion of TE dampens labour productivity growth, not only this could restrain GDP growth, generating the so called growthless job creation condition, but also could re-absorb in the long-run the initial employment growth, generating the honeymoon effect.

The crucial implication is that the expansion of the level of employment could be only transitory and, if the EU governments strive for a structural higher level of employment, they need an ulterior reformatory intervention. In this regard, the main challenge would be to find a labour market regulation able at the same time to eliminate the disincentive to hire and to motivate firms and workers towards more stable and productive job relationships.

Although the identification of such regime is not the aim of this paper, some final remarks are proper. In the light of the results of this paper it would seem justified the prefer- ence expressed by the most part of the literature for a reduction in EPL for PE, rather than the expansion of the use of temporary contracts. However, for both efficiency and equity reasons, it might be more appropriate on one hand to maintain a certain degree of protection for PE, even if certainly smaller than the actual level in Europe; on the other hand, to allow a less intensive use of temporary contracts to facilitate the introduction in the labour market. These considerations would seem to suggest a labour regime providing for a gradual path from temporary to permanent contracts. For these reasons, on one hand the so called flexicurity in Denmark, on the other hand the proposals made by several economists by Lavoce.info (e.g. Ichino 2006; Boeri and Garibaldi 2007b), providing for a single contract ("contratto unico di inserimento") with a gradual path toward job stability and increasing protection, would seem to prompt the right direction.

\section{Executive summary}

Despite the international differences in the relative importance of temporary employment (TE), it is evident that in the last decades temporary jobs have been becoming an important feature of the labour market landscape in the majority of OECD countries. In particular, the share of TE in most EU countries has grown dramatically, both in the form of fixedterm contracts (FTC) and temporary work agencies (TWA), 
raising the question of the possible effects of this structural change in the labour market.

The new scenario has raised concern over the potential increase of the dualism in the labour market between high protected workers finding a stable job and those low protected remaining in the trap of precariousness, with little prospect of upward mobility. Moreover, temporary contracts frequently offer less access to the welfare system and other fringe benefits, as unemployment insurance, sick leave, paid vacations. Indeed, this dualism would represent an undesirable difference between the welfare conditions of these two worker types in the society.

From an efficiency point of view, the increasing share of TE raises the question of what would be the impact on labour productivity. This issue would have potentially very important policy implications, especially since in the last twenty years labour productivity growth accounted for more than half of GDP growth in OECD countries (OECD 2003).

The theoretical literature available so far has not established a clear prediction on the sign of the effect of TE, existing different convincing reasons for both directions. Therefore, the issue of the direction of the effect remains an empirical question. Similarly, while the literature has already offered a convincing answer to the issue of the role of EPL for $\mathrm{PE}$ on employment level, the theoretical literature available so far has not fully clarified what is the impact on labour productivity. Indeed, this question has been already the object of interest of few empirical studies, some of which succeed in identifying the negative impact of EPL for permanent contracts (e.g. Bassanini et al. 2009). However, the strategy to identify the impact of TE does not seem to be as satisfactory as that for PE.

Following this new empirical literature, the aim of this paper is to shed light on this issue by assessing the impact of both EPL for PE and TE (both FTC and TWA) on labour productivity growth. To the extent that the level of TE and EPL affects firms decision on investment and, in turn, the level of capital affects labour productivity growth, we estimate a reduced form model to capture the overall effect, assuming a Cobb-Douglas production function with constant returns to scale. The empirical strategy follows a diff-in-diff approach introduced in the finance literature by Rajan and Zingales (1998) and later extended in other areas in economics. In the field, Micco and Pagés (2006) and Bassanini and Venn (2007) introduced this approach to evaluate the impact of different labour market policies. The method exploits both cross-country variation in EPL for PE and TE and variation in the relevance of EPL in different industries deriving from a particular diff-in-diff assumption.

However, differently from the previous literature we apply this idea of the different binding of EPL across industries only for permanent employment, whereas we implement a different strategy for TE. In fact, as will be argued ahead in the paper, the use of the variation in the EPL index for TE does not seem a proper approach to identify the impact of TE. Differently, it would seem more appropriate to use directly the variation in the share of TE. In this way we should be able to isolate the impact of TE on labour productivity growth, without passing through the relation between the change in the EPL for TE and actual use of temporary contracts in the labour market. Moreover, to the extent that the share of TE might be endogenous and, in particular, driven by the same unobservable factors driving labour productivity, we perform an IV-estimate to check the robustness of our findings. To this extent, our more accurate identification of the effect of the use of TE on labour productivity should represent a valid contribution to the literature.

The main result is that TE has a negative impact on labour productivity growth, even if small in magnitude. In particular, an increase of 10 percentage points of the share of TE would lead to a decrease of about $2-3 \%$ in labour productivity. Furthermore, the analysis confirms the findings of the previous literature that EPL for regular contracts reduce labour productivity growth more in those industries requiring for their own characteristics a greater employment reallocation.

\section{Kurzfassungen}

Ungeachtet internationaler Unterschiede in der Bedeutung befristeter Arbeitsverhältnisse sind diese in den letzten Jahrzehnten in den meisten OECD-Ländern zu einem wichtigen Faktor auf den Arbeitsmärkten geworden. Sowohl Zeitverträge als auch Zeitarbeit haben in den meisten EULändern dramatisch zugenommen. Damit stellt sich die Frage, welche Auswirkungen diese strukturellen Änderungen auf den Arbeitsmarkt haben.

Dieses Szenario hat Sorgen vor einem wachsenden Dualismus auf dem Arbeitsmarkt geweckt - zwischen gut geschützten Arbeitnehmern mit stabiler Beschäftigung einerseits und solchen in prekärer Beschäftigung ohne realistische Aussicht auf Aufstiegsmöglichkeiten andererseits. Hinzu kommt, dass befristete Verträge oft nur beschränkten Zugang zu sozialen und betrieblichen Leistungen bieten, etwa mit Blick auf die Arbeitslosenversicherung, Lohnfortzahlung im Krankheitsfall und bezahlten Urlaub. In der Tat würde ein solcher Dualismus einen gesellschaftlich unerwünschten sozialen Unterschied zwischen beiden Gruppen darstellen.

Unter Effizienzgesichtspunkten stellt sich die Frage, welchen Einfluss der wachsende Anteil befristeter Arbeitsverhältnisse auf die Arbeitsproduktivität hat - eine Frage mit möglicherweise sehr wichtigen politischen Implikationen, insbesondere weil in den letzten 20 Jahren die wachsende Arbeitsproduktivität für mehr als die Hälfte des BIP-Wachstums der OECD-Länder verantwortlich war. 
Die theoretische Literatur erlaubt noch keine klare Vorhersage zum Vorzeichen des Effekts befristeter Beschäftigung auf die Arbeitsproduktivität, da unterschiedliche überzeugende Gründe für Effekte in beide Richtungen bestehen. Daher bleibt die Frage nach der Richtung dieses Effekts eine empirische. Zugleich hat die Literatur schon eine überzeugende Antwort auf die Frage nach dem Einfluss des Kündigungsschutzes auf unbefristete Beschäftigung geliefert, jedoch nicht mit Blick auf die Arbeitsproduktivität. Tatsächlich war dieses Problem schon Gegenstand einiger empirischer Studien, die zum Teil auch schon den negativen Einfluss des Kündigungsschutzes auf unbefristete Beschäftigung identifiziert haben (z.B. Bassanini et al. 2009). Jedoch scheint die Strategie zur Identifizierung des Einflusses von befristeten Arbeitsverhältnissen nicht so zufriedenstellend, wie dies bei dauerhaften Arbeitsverhältnissen der Fall ist.

Dieser neuen Literatur folgend beleuchtet dieser Beitrag die geschilderte Problematik, indem er den Einfluss des Kündigungsschutzes auf das Wachstum der Arbeitsproduktivität für unbefristete und für befristete Beschäftigung (sowohl für Zeitverträge als auch für Zeitarbeit) misst. Dabei berücksichtigen wir, dass das Niveau an befristeter Beschäftigung und Kündigungsschutz die Investitionen von Unternehmen beeinflusst - und damit auch das Wachstum der Arbeitsproduktivität. Dabei schätzen wir den Gesamteffekt mithilfe eines reduzierten Modells, basierend auf einer Cobb-Douglas-Produktionsfunktion mit konstanten Skalenerträgen. Die empirische Strategie folgt einem zunächst in der Finanzliteratur (Rajan und Zingales 1998) eingeführten difference-to-difference-Ansatz, der später auf andere volkswirtschaftliche Bereiche ausgedehnt wurde. Dort haben Micco und Pagés (2006) und Bassanini und Venn (2007) diesen Ansatz eingeführt, um den Effekt verschiedener Maßnahmen der Arbeitsmarktpolitik zu evaluieren. Die Methode nutzt sowohl die internationale Variation beim Kündigungsschutz für befristete und unbefristete Arbeitsverhältnisse als auch die Variation von Branche zu Branche.

Im Unterschied zur bisherigen Literatur wenden wir die Idee der unterschiedlichen Bindungskraft des Kündigungsschutzes nur auf unbefristete Beschäftigungsverhältnisse an, während wir für befristete Beschäftigungsverhältnisse eine andere Strategie anwenden. Tatsächlich scheint die Nutzung von Variationen des Kündigungsschutzindex ' für die befristete Beschäftigung nicht geeignet. Angemessener hingegen scheint es, die Variation beim Anteil der befristeten Beschäftigung direkt zu nutzen. Durch diesen Ansatz sollte es uns möglich sein, den Einfluss der befristeten Beschäftigung auf das Wachstum der Arbeitsproduktivität zu isolieren, ohne auf den Zusammenhang zwischen der Änderung beim Kündigungsschutz für befristete Beschäftigung und der tatsächlicher Nutzung von befristeten Beschäftigung eingehen zu müssen. Nachdem der Anteil der befristeten Beschäftigung auch endogen und von den selben unbeobachtbaren Faktoren getrieben sein könnte wie die Arbeitspproduktivität, führen wir eine IV-Schätzung durch, um die Robustheit unserer Ergebnisse zu testen. Insofern sollte unsere genauere Identifikation des Effekts der Nutzung von befristeter Beschäftigung auf die Arbeitsproduktivität ein valider Beitrag zur Literatur sein.

Der zentrale Befund ist, dass befristete Beschäftigung einen negativen, aber nur geringen Einfluss auf das Wachstum der Arbeitsproduktivität hat. So würde eine Steigerung des Anteils befristet Beschäftigter um 10 Prozentpunkte zu einer Verringerung der Arbeitsproduktivität um zirka 2-3\% führen. Außerdem bestätigt die Analyse die Befunde aus der bisherigen Literatur, dass der Kündigungsschutz für unbefristete Arbeitsverhältnisse das Wachstum der Arbeitsproduktivität insbesondere in den Branchen reduziert, die aufgrund spezifischer Merkmale einer stärkeren Beschäftigungsreallokation bedürfen.

\section{Appendix 1: Data description}

\section{Labour Productivity}

Definition: gross value added in volume terms (base $1995=$ 100 ) divided by total hours worked (variable $L P \_I$ in EU KLEMS database)

$y_{i j t}=\frac{(V A / L)_{i j t}}{(V A / L)_{i j 1995}} * 100$

Source: EU KLEMS database.

\section{Total Hours Worked}

Definition: product of average hours worked and total person engaged.

Source: EU KLEMS database.

\section{Employment Level}

Definition: total persons engaged.

Source: EU KLEMS database.

\section{Job Reallocation Rate}

Definition: Davis and Haltiwanger measure of job reallocation rate $J R_{i j t}=\frac{\left|E_{i j t}-E_{i j t-1}\right|}{\left(E_{i j t}+E_{i j t-1}\right) / 2}$.

Source: own calculation from the employment level data from EU KLEMS database.

\section{Frictionless Job Reallocation Rate}

Definition: job reallocation rate depurated from the frictions introduced by labour market regulation and the effect of aggregate shocks $\left(F J R_{j}=\hat{\pi}_{j}\right)$.

Source: own estimation. 
Share of Temporary Employment

Definition: the share of persons engaged with temporary contracts over total person engaged. A job may be considered temporary if employer and employee agree that its end is determined by objective conditions such as a specific date, the completion of a task or the return of another employee who has been temporarily replaced. The following belong to these categories:

- Persons with fixed-term contracts (FTC);

- Persons engaged by an agency (TWA) and hired to a third party to perform a specific task (unless there is a written work contract of unlimited duration with the agency);

- Persons with seasonal employment;

- Persons with specific training contracts (if there are no objective criteria for the end of a job or work contract, this should be considered permanent or of unlimited duration);
- Persons on probationary period.

Source: EUROSTAT Labour Force Survey.

EPL for Permanent Employment

Definition: OECD index of the stringency of employment protection legislation on regular contracts.

Source: OECD Employment Outlook (2004).

EPL for Temporary Employment

Definition: OECD index of the permissiveness on the use of temporary contracts.

Source: OECD Employment Outlook (2004).

Trade Union Density

Definition: employees trade union members divided by total number of employees.

Source: OECD Labour Force Statistics.

\section{Appendix 2: Descriptive statistics}

Table 8 Descriptive statistics

\begin{tabular}{|c|c|c|c|c|c|}
\hline Variable & Obs & Mean & Std. Dev. & Min & Max \\
\hline Labour Productivity & 1820 & 108.565 & 20.757 & 63.486 & 268.792 \\
\hline Log Labour Productivity & 1820 & 4.672 & 0.170 & 4.151 & 5.594 \\
\hline Job Reallocation & 1820 & 0.028 & 0.027 & 0.000 & 0.239 \\
\hline Frictionless Job Reallocation & 1820 & 0.043 & 0.009 & 0.028 & 0.059 \\
\hline Share of TE & 1820 & 0.089 & 0.075 & 0.000 & 0.488 \\
\hline EPL for Regular Contracts & 1820 & 2.372 & 0.846 & 0.948 & 4.333 \\
\hline EPL for Temporary Contracts & 1820 & 2.259 & 1.278 & 0.250 & 5.375 \\
\hline Trade Union Density & 1820 & 0.408 & 0.232 & 0.080 & 0.839 \\
\hline
\end{tabular}

Table 9 Industry descriptive statistics

\begin{tabular}{llll}
\hline Industry & $\hat{\pi}_{j}$ & $\overline{T E}_{j}$ & $\overline{L P}_{j}$ \\
\hline Agriculture, Hunting and Forestry & 0.049 & 0.080 & 114.148 \\
Total Manufacturing & 0.038 & 0.082 & 114.334 \\
Electricity, Gas and Water Supply & 0.059 & 0.054 & 122.143 \\
Construction & 0.045 & 0.118 & 99.984 \\
Wholesale and Retail Trade & 0.028 & 0.089 & 108.360 \\
Hotels and Resturants & 0.040 & 0.156 & 100.076 \\
Transport, Storage and Communication & 0.036 & 0.073 & 113.630 \\
Financial Intermediation & 0.039 & 0.059 & 105.747 \\
Real Estate, Renting and Business Activities & 0.057 & 0.104 & 96.763 \\
Other Community, Social and Personal Services & 0.040 & 0.144 & 100.495 \\
& & $\rho\left(\overline{T E}_{j}, \overline{L P}_{j}\right)=-0.746$ \\
\hline
\end{tabular}


Table 10 Country descriptive statistics

Table 11 Share of temporary employment (first-stage 2SLS)

FS: first-stage estimates of the IV regression; EPL for TE: employment protection legislation for temporary employment; EPL for PE: employment protection legislation for permanent employment; FJR: frictionless job reallocation; BI 1: binary indicator 1; BI2: binary indicator 2; PE: the share of permanent employment; TUD: trade union density

HAC Robust standard errors in brackets. *significant at $10 \%$, ** significant at $5 \%$,

*** significant at $1 \%$

${ }^{a}$ First-stage estimates of the

IV-FE regression in Table 1.

${ }^{b}$ First-stage estimates of the IV-FE regression in Table 2.

${ }^{\mathrm{c}}$ First-stage estimates of the IV-FE regression in Table 3. ${ }^{\mathrm{d}}$ First-stage estimates of the IV-FE regression in Table 4

\begin{tabular}{lcc}
\hline Country & $\overline{T E}_{i}$ & $\overline{L P}_{i}$ \\
\hline Austria & 0.051 & 107.346 \\
Belgium & 0.045 & 106.458 \\
Denmark & 0.078 & 104.438 \\
Finland & 0.091 & 109.182 \\
France & 0.099 & 109.834 \\
Germany & 0.100 & 108.693 \\
Ireland & 0.044 & 115.777 \\
Italy & 0.066 & 102.162 \\
Netherlands & 0.102 & 108.225 \\
Portugal & 0.103 & 113.535 \\
Spain & 0.242 & 103.899 \\
Sweden & 0.084 & 108.990 \\
United Kingdom & 0.050 & 112.809 \\
& & \\
\hline
\end{tabular}

\begin{tabular}{|c|c|c|c|c|}
\hline & $\begin{array}{l}\text { (1) } \\
\mathrm{FS}^{\mathrm{a}}\end{array}$ & $\begin{array}{l}\text { (2) } \\
\mathrm{FS}^{\mathrm{b}}\end{array}$ & $\begin{array}{l}\text { (3) } \\
\text { FS }^{\mathrm{c}}\end{array}$ & $\begin{array}{l}(4) \\
F^{d}\end{array}$ \\
\hline EPL for TE & $\begin{array}{l}-0.012 \\
(0.002)^{* * *}\end{array}$ & $\begin{array}{l}-0.020 \\
(0.003)^{* * *}\end{array}$ & $\begin{array}{l}-0.012 \\
(0.002)^{* * *}\end{array}$ & $\begin{array}{l}-0.012 \\
(0.002)^{* * *}\end{array}$ \\
\hline EPL for PE & $\begin{array}{l}0.032 \\
(0.004)^{* * *}\end{array}$ & & $\begin{array}{l}0.015 \\
(0.003)^{* * *}\end{array}$ & $\begin{array}{l}0.017 \\
(0.003)^{* * *}\end{array}$ \\
\hline EPL*FJR & $\begin{array}{l}-0.343 \\
(0.087)^{* * *}\end{array}$ & & & \\
\hline $\mathrm{EPL} * \mathrm{PE}$ & & $\begin{array}{l}-0.005 \\
(0.006)\end{array}$ & & \\
\hline EPL*PE*FJR & & $\begin{array}{l}-0.416 \\
(0.080)^{* * *}\end{array}$ & & \\
\hline EPL*BI1 & & & $\begin{array}{l}0.005 \\
(0.002)^{*}\end{array}$ & \\
\hline EPL*BI2 & & & & $\begin{array}{l}0.001 \\
(0.001)\end{array}$ \\
\hline TUD & $\begin{array}{l}-0.001 \\
(0.000)^{* *}\end{array}$ & $\begin{array}{l}-0.001 \\
(0.000)^{* * *}\end{array}$ & $\begin{array}{l}-0.001 \\
(0.001)^{* *}\end{array}$ & $\begin{array}{l}-0.001 \\
(0.000)^{* *}\end{array}$ \\
\hline Trend & $\begin{array}{l}0.051 \\
(0.068)\end{array}$ & $\begin{array}{l}0.133 \\
(0.068)^{*}\end{array}$ & $\begin{array}{l}0.051 \\
(0.068)\end{array}$ & $\begin{array}{l}0.051 \\
(0.068)\end{array}$ \\
\hline Sector dummies & YES & YES & YES & YES \\
\hline Country dummies & YES & YES & YES & YES \\
\hline Year dummies & YES & YES & YES & YES \\
\hline Observations & 1820 & 1820 & 1820 & 1820 \\
\hline R-squared & 0.8537 & 0.8564 & 0.8530 & 0.8521 \\
\hline
\end{tabular}


Table 12 Conditions to get access to fringe benefits

\begin{tabular}{|c|c|c|c|c|}
\hline & Paid holidays & Sick leave & Unemployment benefit & Parental leave \\
\hline & Employment duration & Contribution period & Contribution period & Contribution period \\
\hline Austria & 6 months & $\begin{array}{l}\text { Not for all TE, various } \\
\text { earnings thresholds }\end{array}$ & $\begin{array}{l}52 \text { weeks in the last } 2 \text { years, } \\
\text { earnings threshold }\end{array}$ & Earnings threshold \\
\hline Belgium & All & 3 months & $\begin{array}{l}\text { Various conditions, more } \\
\text { days for older group }\end{array}$ & All \\
\hline Denmark & All & $>72$ hours in past 8 weeks & 52 weeks in the last 3 years & 72 hours in the last 8 weeks \\
\hline Finland & $>35$ hours per months & All & $\begin{array}{l}43 \text { weeks in the last } 2 \text { years } \\
>18 \text { hours per week }\end{array}$ & All \\
\hline France & 1 month & 800 hours in the last years & $\begin{array}{l}4 \text { months in the last } 18 \\
\text { months }\end{array}$ & 800 hours in the last year \\
\hline Germany & All pro rata & All & 12 months in the last 3 years & All \\
\hline Italy & All & $\begin{array}{l}\text { Various conditions } \\
\text { depending on TE }\end{array}$ & 52 weeks in the last 2 years & All \\
\hline Netherlands & All & All & 26 weeks in the last 36 weeks & All \\
\hline Portugal & 30 days & 6 months & 18 months & 6 months \\
\hline Spain & Various conditions & Various conditions & 360 days in the last 6 years & All \\
\hline Sweden & All & All & 6 months in the last year & All \\
\hline United Kingdom & $\begin{array}{l}13 \text { weeks and not } \\
\text { statutory for few } \\
\text { sectors }\end{array}$ & $\begin{array}{l}3 \text { months earnings }> \\
\text { threshold }\end{array}$ & $\begin{array}{l}\text { Employment conditions in } \\
\text { the last } 2 \text { years }\end{array}$ & $\begin{array}{l}26 \text { weeks and earnings } \\
\text { threshold }\end{array}$ \\
\hline
\end{tabular}

Source: OECD, Employment Outlook. Data collected directly from OECD Member Governments

Table 13 Working conditions of temporary workers (share of TE among respondents)

\begin{tabular}{|c|c|c|c|c|c|c|c|c|c|c|c|}
\hline & \multicolumn{2}{|c|}{ Second job } & \multicolumn{3}{|c|}{ Shift work } & \multicolumn{3}{|c|}{ Saturday work } & \multicolumn{3}{|c|}{ Sunday work } \\
\hline & No & Yes & Often & Some & Never & Often & Some & Never & Often & Some & Never \\
\hline Austria & 8.1 & 3.5 & 5.9 & 9.7 & 8.3 & 10.2 & 6.6 & 7.5 & 8.7 & 8.3 & 7.8 \\
\hline Belgium & 9.0 & 7.8 & 7.4 & - & 9.1 & 10.0 & 7.7 & 9.5 & 10.5 & 7.8 & 9.3 \\
\hline Denmark & 9.7 & 13.0 & 12.6 & 11.4 & 9.9 & 10.7 & 8.7 & 10.3 & 10.3 & 8.0 & 10.5 \\
\hline Finland & 17.5 & 22.7 & 17.9 & - & 17.6 & 16.8 & 18.0 & 17.8 & 17.1 & 18.4 & 17.6 \\
\hline France & 14.4 & 17.1 & 15.8 & - & 14.4 & 14.2 & 12.5 & 15.6 & 16.3 & 11.6 & 15.0 \\
\hline Germany & 12.7 & 10.2 & 8.6 & 12.5 & 12.0 & 10.1 & 9.6 & 12.6 & 10.7 & 11.3 & 11.7 \\
\hline Ireland & 4.3 & 5.0 & 8.2 & 11.8 & 9.4 & 9.5 & 7.5 & 10.5 & 10.7 & 9.3 & 9.2 \\
\hline Italy & 10.1 & 16.6 & 8.3 & 11.4 & 10.5 & 10.6 & 8.5 & 10.5 & 10.7 & 10.1 & 10.1 \\
\hline Netherlands & 13.3 & 23.0 & 17.4 & 13.3 & 14.1 & 17.8 & 10.3 & 13.9 & 14.9 & 12.4 & 14.5 \\
\hline Portugal & 20.6 & 18.5 & 20.6 & - & 20.4 & 25.4 & - & 19.2 & 28.0 & - & 19.6 \\
\hline Spain & 32.2 & 30.0 & 25.8 & 22.5 & 33.6 & 25.6 & 29.3 & 32.1 & 33.5 & 25.4 & 33.2 \\
\hline Sweden & 14.3 & 17.3 & 15.9 & 30.9 & 13.6 & 18.3 & 17.3 & 12.5 & 17.8 & 17.3 & 12.9 \\
\hline United Kingdom & 6.5 & 11.7 & 14.5 & 5.5 & 6.9 & 5.7 & 4.7 & 8.9 & 7.0 & 4.5 & 7.6 \\
\hline
\end{tabular}

Source: OECD, Employment Outlook. Data supplied by EUROSTAT, Labour Force Survey

\section{Appendix 3: Temporary employment}

Potential problems in the LFS measure of temporary employment Despite the LFS measure of TE arguably should be the best measure for our study, still there might be some potential problems in the implementation of such measure:
- The classification of workers on training or probationary contracts might not be consistent across countries in the sample. When there is an expectation that employers will provide a permanent contract to trainees or probationary workers performing well, the classification of such workers as temporary defers to the subjective judg- 
Table 14 Job satisfaction of temporary workers (relative to permanent workers)

Source: OECD, Employment Outlook. Data from the European Community Household Panel

\begin{tabular}{lcccc}
\hline & Overall satisfaction & Pay & Job security & Working conditions \\
\hline Austria & 96.3 & 94.9 & 84.5 & 99.2 \\
Belgium & 100.6 & 96.0 & 74.6 & 105.1 \\
Denmark & 98.5 & 92.0 & 72.6 & 96.3 \\
Finland & 101.1 & 92.4 & 66.3 & 101.9 \\
France & 95.5 & 92.8 & 61.3 & 102.3 \\
Germany & 95.1 & 97.3 & 82.7 & 99.0 \\
Ireland & 94.4 & 90.6 & 64.9 & 101.4 \\
Italy & 84.2 & 84.9 & 62.1 & 93.8 \\
Netherlands & 98.9 & 94.7 & 73.5 & 107.1 \\
Portugal & 91.3 & 92.6 & 71.5 & 98.6 \\
Spain & 90.6 & 89.9 & 63.6 & 96.2 \\
United Kingdom & 95.9 & 89.2 & 74.3 & - \\
\hline
\end{tabular}

ment of the national statistical office, which indeed might differ across countries;

- It is usually argued that certain forms of self-employment are not significantly different from some forms of temporary employment included in the LFS definition. For instance, in Italy the contract "co-ordinated and continuous collaboration" between employers and self-employed workers are usually considered a form of temporary employment. The same can be said for the "contract for work and services" in Austria. Nonetheless, they are classified as self-employment and certainly they are excluded from the LFS measure of TE. Therefore, as long as there are differences across countries in the contracting forms used for such workers, this might generate a discrepancy in the international comparability of the LFS measure of TE;

- Countries with the same level of overall TE might significantly differ in the composition among the different forms of temporary contracts. Indeed, these different forms (e.g. FTC, TWA) might have quite different conditions for pay and other employment aspects and, therefore, might potentially have different implications for labour market performance. Nonetheless, by using the LFS measure of TE we are not able to distinguish among the different forms of temporary contracts. Unfortunately, data on the different forms of TE are not available for a wide sample of EU countries.

\section{References}

Angrist, J.D., Pischke, J.S.: Mostly Harmless Econometrics: An Empiricist's Companion. Princeton University Press, Oxford (2009)

Autor, D., Donohue, J., Schwab, S.J.: The costs of wrongful-discharge laws. Rev. Econ. Stat. 88(2), 211-231 (2006)

Baker, D., Glyn, A., Howell, D., Schmitt, J.: Labour market institutions and unemployment: assessment of the cross-country evidence. In: Howell, D. (ed.) Fighting Unemployment: The Limits of Free Market Orthodoxy. Oxford University Press, Oxford (2004)
Bartelsman, E.J., Hinloopen, J.: Unleashing animal spirits: investment in ICT and economic growth. In: Soete, L., ter Weel, B. (eds.) The Economics of the Digital Society. Edward Elgar, Northampton (2005)

Bassanini, A., Venn, D.: Assessing the impact of labour market policies on productivity: a difference-in-differences approach. OECD Social Employment and Migration Working Papers, No. 54. OECD Publishing (2007)

Bassanini, A., Booth, A.L., Brunello, G., De Paola, M., Leuven, E.: Workplace training in Europe. In: Brunello, G., Garibaldi, P., Wasmer, E. (eds.) Education and Training in Europe. Oxford University Press, Oxford (2007)

Bassanini, A., Nunziata, L., Venn, D.: Job protection legislation and productivity growth in OECD countries. Econ. Policy 24, 349402 (2009)

Belot, M., Boone, J., van Ours, J.C.: Welfare effects of employment protection. CEPR Discussion Paper No. 3396 (2002)

Bentolila, S., Bertola, G.: Firing costs and labour demand: how bad is eurosclerosis. Rev. Econ. Stud. 57(3), 381-402 (1990)

Bertola, G.: Job security, employment and wages. Eur. Econ. Rev. 34(4), 851-866 (1990)

Blanchard, O., Portugal, P.: What hides behind an unemployment rate. Comparing Portuguese and US unemployment. Am. Econ. Rev. 91(1), 187-207 (2001)

Boeri, T., Garibaldi, P.: Two tier reforms of employment protection legislation. A honeymoon effects. Econ. J. 117, 357-385 (2007a)

Boeri, T., Garibaldi, P.: Il "Testo Unico" del contratto unico. http:// www.lavoce.info, Lavoro (2007b)

Ciccone, A., Papaioannou, E.: Adjustment to target capital, finance and growth. UPF Economics Working Papers No. 982 (2006)

Ciccone, A., Papaioannou, E.: Red tape and delayed entry. J. Eur. Econ. Assoc. 5, 444-458 (2007)

Cingano, F., Leonardi, M., Messina, J., Pica, G.: The effect of employment protection legislation and financial market imperfections on investment: evidence from a firm-level panel of EU countries. Econ. Policy 25(61), 117-163 (2010)

Davis, S.J., Haltiwanger, J.C.: Gross job creation, gross job destruction and employment reallocation. Q. J. Econ. 107(3), 819-863 (1992)

DeFreitas, G., Marshall, A.: Labour surplus, worker rights and productivity growth: a comparative analysis of Asia and Latin America. Labour 12(3), 515-539 (1998)

Destefanis, S., Mastromatteo, G.: Labour-market performance in the OECD: some recent cross-country evidence. Int. J. Manpow. 31(7), 713-731 (2010) 
Dolado, J.J., Stucchi, R.: Do temporary contracts affects TFP? Evidence from Spanish manufacturing firms. CEPR Discussion Paper No. 7055 (2008)

Engellandt, A., Riphahn, R.: Temporary contracts and employee effort. CEPR Discussion Paper No. 4178 (2004)

Fella, G.: Efficiency wage and efficient redundancy pay. Eur. Econ. Rev. 44, 1473-1490 (2004)

Fisman, R., Love, I.: Financial dependence and growth revisited. J. Eur. Econ. Assoc. 5(2), 470-479 (2007)

Garibaldi, P.: Job flow dynamics and firing restrictions. Eur. Econ. Rev. 42(2), 245-275 (1998)

Garibaldi, P., Violante, G.: The employment effects of severance payments with wage rigidities. Econ. J. 115, 799-832 (2005)

Guell, M., Petrongolo, B.: How binding are legal limits? Transitions from temporary to permanent work in Spain. Labour Econ. 14(2), 153-183 (2007)

Hopenhayn, H., Rogerson, R.: Job turnover and policy evaluation: a general equilibrium analysis. J. Polit. Econ. 101(5), 915-938 (1993)

Ichino, A.: Come superare il dualismo nel mercato del lavoro. http:// www.lavoce.info, Lavoro (2006)

Ichino, A., Riphahn, R.T.: The effect of employment protection on worker effort: a comparison of absenteeism during and after probation. J. Eur. Econ. Assoc. 3(1), 120-143 (2005)

Ichino, A., Mealli, F., Nannicini, T.: Temporary work agencies in Italy: a springboard toward permanent employment? G. Econ. Ann. Econ. 64(1), 1-27 (2005)

Koeniger, W.: Dismissal costs and innovation. Econ. Lett. 88(1), 79-85 (2005)

Kvasnicka, M.: Does temporary help work provide a stepping stone to regular employment? NBER Working Paper No. 13843 (2008)

Lisi, D.: Analysis of employment protection legislation: a model with endogenous labour productivity. J. Acad. Res. Econ. 4, 209-245 (2012)

Messina, J., Vallanti, G.: Job flow dynamics and firing restrictions: the European evidence. Econ. J. 117, 279-301 (2007)

Micco, A., Pagés, C.: The economic effects of employment protection: evidence from international industry-level data. IZA Discussion Paper No. 2433 (2006)

Mortensen, D.T., Pissarides, C.A.: Unemployment responses to "skillbiased" shocks: the role of labour market policy. Econ. J. 109, 242-265 (1999)
Nickell, S.: Fixed costs, employment and labour demand over the cycle. Economica 45, 329-345 (1978)

Nickell, S., Layard, R.: Labour market institutions and economic performance. In: Ashenfelter, O., Card, D. (eds.) Handbook of Labour Economics. North Holland, Amsterdam (1999)

Nickell, S., Nunziata, L., Ochel, W.: Unemployment in the OECD since the 1960s. What do we know? Econ. J. 115, 1-27 (2005)

OECD: OECD Employment Outlook. OECD, Paris (1999)

OECD: OECD Employment Outlook. OECD, Paris (2002)

OECD: The Sources of Economic Growth in OECD Countries. OECD, Paris (2003)

OECD: OECD Employment Outlook. OECD, Paris (2004)

OECD: OECD Employment Outlook. OECD, Paris (2007a)

OECD: More jobs but less productive? The impact of labour market policies on productivity: further material (2007b) http://www. oecd.org/dataoecd/57/28/38608694.pdf

Rajan, R., Zingales, L.: Financial dependence and growth. Am. Econ. Rev. 88, 559-586 (1998)

Riphahn, R.T.: Employment protection and effort among German employees. Econ. Lett. 85(3), 353-357 (2004)

Saint-Paul, G.: Is labour rigidity harming Europe's competitiveness? The effect of job protection on the pattern of trade and welfare. Eur. Econ. Rev. 41(3-5), 499-506 (1997)

Saint-Paul, G.: Employment protection, international specialization and innovation. Eur. Econ. Rev. 46(2), 375-395 (2002)

Samaniego, R.: Employment protection and high-tech aversion. Rev. Econ. Dyn. 9(2), 224-241 (2006)

Wooldridge, J.M.: Econometric Analysis of Cross Section and Panel Data, 2nd edn. MIT Press, Cambridge (2010)

Domenico Lisi studied Economics at the University of Catania, University College London and Barcelona GSE. MSc in Economics at the University College London in 2009. PhD in Public Economics at the University of Catania in 2011. He is currently Post Doc at the Department of Economics and Business, University of Catania. Research Visits in University College London and Collegio Carlo Alberto. Research interests: labour economics, health economics, social policy, applied economics. 